
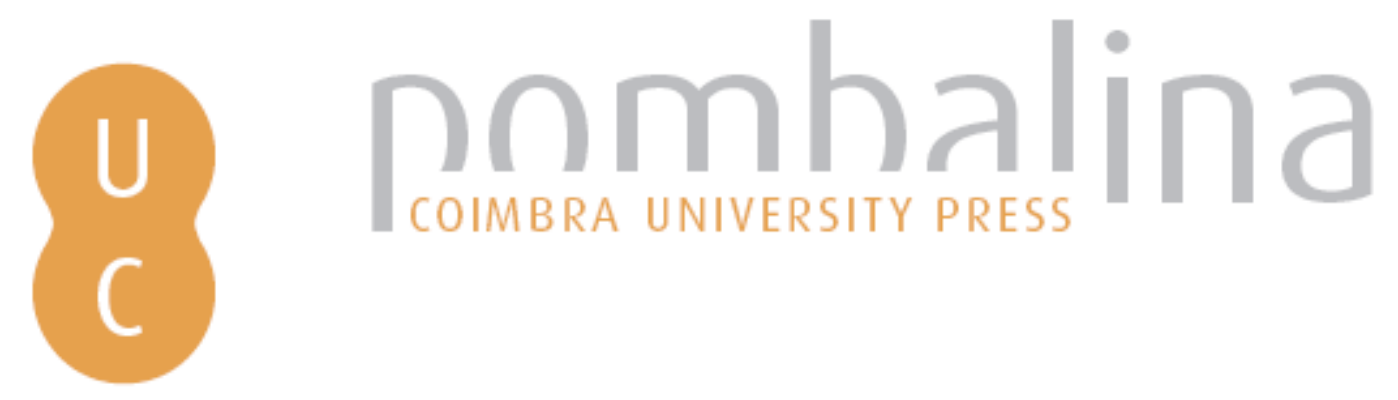

Literatura e Medicina: alguns textos de Justo Lípsio e de dois doutores Luís Nunes

Autor(es): $\quad$ Pinto, António Guimarães

Publicado por: UA Editora - Universidade de Aveiro; Imprensa da Universidade de

URL

persistente: URI:http://hdl.handle.net/10316.2/35693

DOI: $\quad$ DOI:http://dx.doi.org/10.14195/978-989-26-0941-6_7

Accessed : $\quad$ 26-Apr-2023 13:37:57

A navegação consulta e descarregamento dos títulos inseridos nas Bibliotecas Digitais UC Digitalis, UC Pombalina e UC Impactum, pressupõem a aceitação plena e sem reservas dos Termos e Condições de Uso destas Bibliotecas Digitais, disponíveis em https://digitalis.uc.pt/pt-pt/termos.

Conforme exposto nos referidos Termos e Condições de Uso, o descarregamento de títulos de acesso restrito requer uma licença válida de autorização devendo o utilizador aceder ao(s) documento(s) a partir de um endereço de IP da instituição detentora da supramencionada licença.

Ao utilizador é apenas permitido o descarregamento para uso pessoal, pelo que o emprego do(s) título(s) descarregado(s) para outro fim, designadamente comercial, carece de autorização do respetivo autor ou editor da obra.

Na medida em que todas as obras da UC Digitalis se encontram protegidas pelo Código do Direito de Autor e Direitos Conexos e demais legislação aplicável, toda a cópia, parcial ou total, deste documento, nos casos em que é legalmente admitida, deverá conter ou fazer-se acompanhar por este aviso.

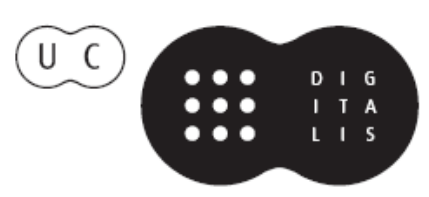




\section{HUMANISMO E CIÊNCIA Antiguidade e Renascimento}

António Manuel Lopes Andrade

Carlos de Miguel Mora

João Manuel Nunes Torrão
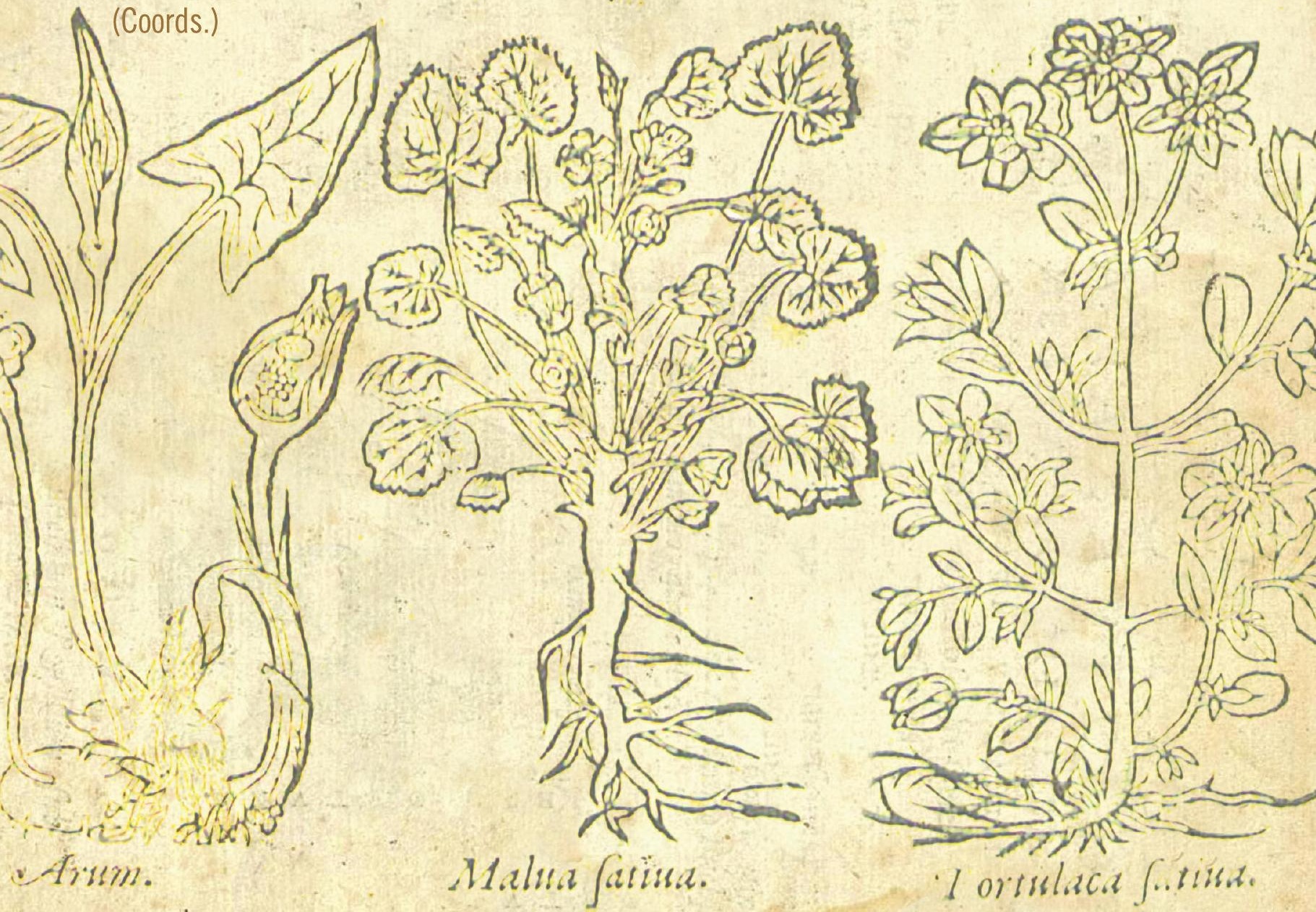

Aveiro I Coimbra I São Paulo 2015

UA Editora - Universidade de Aveiro I Imprensa da Universidade de Coimbra I Annablume 
Este volume resulta de várias iniciativas desenvolvidas no âmbito do projecto de I\&D "Dioscórides e o Humanismo Português: os Comentários de Amato Lusitano" (http://amatolusitano.web.ua.pt), recoIhendo contribuições de mais de duas dezenas de colaboradores, tanto de membros da equipa como de outros investigadores nacionais e estrangeiros. Entre os eventos que estiveram na origem deste livro destacam-se as três edições do Ciclo de Conferências promovido pelo projecto, realizadas entre 2010 e 2013, e sobretudo o Colóquio Internacional "Dioscórides e o Humanismo Português: os Comentários de Amato Lusitano", que decorreu no Departamento de Línguas e Culturas da Universidade de Aveiro, nos dias 21 e 22 de Novembro de 2013.

0 objectivo principal do projecto é a edição e tradução para português dos dois livros que Amato Lusitano dedicou ao comentário do tratado grego De materia medica de Dioscórides, ou seja, o Index Dioscoridis (Antuérpia, 1536) e as In Dioscoridlis Anazarbei de medica materia libros quinque... enarrationes (Veneza, 1553), estando contemplada, também, a tradução de mais duas obras directamente correlacionadas com os livros do médico português: a montante, a do próprio tratado grego de Dioscórides; a jusante, a do livro intitulado Apologia adversus Amathum Lusitanum (Veneza, 1558) de Pietro Andrea Mattioli.

OBRA PUBLICADA COM A COORDENAÇÃO

CIENTÍFICA DE:

Centro de Línguas, Literaturas e Culturas da Universidade de Aveiro

Centro de Estudos Clássicos e Humanísticos da Universidade de Coimbra

Cátedra de Estudos Sefarditas "Alberto

Benveniste" da Faculdade de Letras da Universidade de Lisboa 


\section{HUMANISMO E CIÊNCIA}

\section{Antiguidade e Renascimento}

ANTÓNIO MANUEL LOPES ANDRADE

CARLOS DE MIGUEL MORA

JOÃO MANUEL NUNES TORRÃO

(COORDS.)

AVEIRO • COIMBRA • SÃO PAULO

2015

UA EDITORA • UNIVERSIDADE DE AVEIRO

IMPRENSA DA UNIVERSIDADE DE COIMBRA

ANNABLUME 


\section{HUMANISMO E CIÊNCIA: Antiguidade e Renascimento}

\author{
EDIÇÃO

UA EDITORA • UNIVERSIDADE DE AVEIRO
IMPRENSA DA UNIVERSIDADE DE COIMBRA
ANNABLUME

ORGANIZAÇÃO E COORDENAÇÃO EDITORIAL ANTÓNIO MANUEL LOPES ANDRADE

CARLOS DE MIGUEL MORA

JOÃO MANUEL NUNES TORRÃO

\author{
DESIGN DA CAPA \\ MEIOKILO DESIGN STUDIO
}

DESIGN

CARLOS COSTA

IMPRESSÃO E ACABAMENTO

SERSILITO • MAIA

ISBN

UA • 978-972-789-434-5

IUC • 978-989-26-0940-9

\section{ISBN DIGITAL}

UA • 978-972-789-435-2

IUC • 978-989-26-0941-6

DOI

http://dx.doi.org/10.14195/ 978-989-26-0941-6

DEPÓSITO LEGAL 368241/13

TIRAGEM 500 Exemplares

(C) 2015

UA EDITORA • UNIVERSIDADE DE AVEIRO IMPRENSA DA UNIVERSIDADE DE COIMBRA

ANNABLUME

\section{COMISSÃO CIENTÍFICA}

António Manuel Lopes Andrade

Carlos de Miguel Mora

Delfim Ferreira Leão

Henrique Leitão

João Manuel Nunes Torrão

Maria de Fátima Reis

Maria do Céu Zambujo Fialho

Miguel Ángel González Manjarrés

\section{TEXTOS}

Adelino Cardoso

Ana Leonor Pereira

Ana Margarida Borges

António Guimarães Pinto

António Maria Martins Melo

Bernardo Mota

Carlos A. Martins de Jesus

Carlos de Miguel Mora

Cristina Santos Pinheiro

Donald Beecher

Emília Oliveira

Isabel Malaquias

James W. Nelson Novoa

Joana Mestre Costa

João Manuel Nunes Torrão

João Rui Pita

Jorge Paiva

José Sílvio Moreira Fernandes

Maria de Fátima Silva

Miguel Ángel González Manjarrés

Rui Manuel Loureiro

Telmo Corujo dos Reis

Teresa Nobre de Carvalho

Vinicije B. Lupis

Virgínia Soares Pereira 


\section{HUMANISMO E CIÊNCIA}

\section{Antiguidade e Renascimento}

ANTÓNIO MANUEL LOPES ANDRADE

CARLOS DE MIGUEL MORA

JOÃO MANUEL NUNES TORRÃO

(COORDS.)

AVEIRO • COIMBRA • SÃO PAULO

2015

UA EDITORA • UNIVERSIDADE DE AVEIRO

IMPRENSA DA UNIVERSIDADE DE COIMBRA

ANNABLUME 
OBRA PUBLICADA

COM A COORDENAÇÃO

CIENTÍFICA DE:

CENTRO DE LÍNGUAS,

LITERATURAS E CULTURAS DA

UNIVERSIDADE DE AVEIRO

CENTRO DE ESTUDOS

CLÁSSICOS E HUMANÍSTICOS DA

UNIVERSIDADE DE COIMBRA

CÁTEDRA DE ESTUDOS SEFARDITAS

"ALBERTO BENVENISTE"

DA FACULDADE DE LETRAS DA

UNIVERSIDADE DE LISBOA 


\section{SUMÁRIO}

PREFÁCIO

1.1 "Teofrasto, Tratado das plantas. No alvor de uma nova ciência" 13

Maria de Fátima Silva

1.2 "Francisco de Melo e os fragmentos de teoria óptica de Pierre Brissot" 21 Bernardo Mota

1.3 "Algumas reflexões sobre as pedras preciosas nos Colóquios dos simples de Garcia de Orta" 37 Rui Manuel Loureiro

1.4 "Estratégias, patronos e favores em Colóquios dos Simples de Garcia de Orta" 63 Teresa Nobre de Carvalho

1.5 "As plantas na obra poética de Camões (épica e lírica)" 95 Jorge Paiva

1.6 "Nicolás Monardes, John Frampton and the Medical Wonders of the New World" .141 Donald Beecher

1.7 "Literatura e Medicina: alguns textos de Justo Lípsio e de dois doutores Luís Nunes" 161 António Guimarães Pinto

1.8 "Ontologias e idiossincrasias dos Amantes, à luz da Archipathologia de Filipe Montalto" ...... 211 Joana Mestre Costa \& Adelino Cardoso

1.9 "Gabriel da Fonseca. A New Christian doctor in Bernini's Rome". .227 James W. Nelson Novoa 


\section{2) DIOSCÓRIDES E O HUMANISMO PORTUGUÊS: OS COMENTÁRIOS DE AMATO LUSITANO}

2.1 "Léxico científico português nos Comentários de Amato: antecedentes e receção"

Ana Margarida Borges

2.2 "Usos medicinais das plantas, em Amato Lusitano: o bálsamo"

António Maria Martins Melo

2.3 "Amato Lusitano e a importância da ilustração botânica no século xVI.

Em torno das edições lionesas das Enarrationes (1558)"

Carlos A. Martins de Jesus

2.4 "Sobre la identificación entre ébano y guayaco en una entrada

del Index Dioscoridis de Amato Lusitano".

Carlos de Miguel Mora

2.5 "Os partos distócicos em Amato Lusitano e em Rodrigo de Castro:

fontes, doutrinas e terapias greco-romanas"

\section{Cristina Santos Pinheiro}

2.6 "Do carvalho ao castanheiro: usos e propriedades medicinais

de fagáceas nas Enarrationes de Amato Lusitano".

Emília Oliveira

2.7 "O mundo mineral nos Comentários a Dioscórides de Amato Lusitano".

Isabel Malaquias \& Virgínia Soares Pereira

2.8 "Alguns comentários de Amato: entre a estranheza e a realidade"

João Manuel Nunes Torrão

2.9 "Caracterização e usos terapêuticos de produtos de origem marinha

nos Comentários de Amato Lusitano a Dioscórides"

José Sílvio Moreira Fernandes

2.10 "La mandrágora de Amato Lusitano: edición, traducción y anotación"

Miguel Ángel González Manjarrés

2.11 "O vinho e os vinhos - usos e virtudes de um dom dos deuses

nas Enarrationes de Amato Lusitano"

Telmo Corujo dos Reis

2.12 "Amatus Lusitanus e Didaco Pirro: due ebrei portoghesi

e cerchia umanistica di Dubrovnik" 481

Vinicije B. Lupis

2.13 "Estudos contemporâneos sobre Amato Lusitano". 513

João Rui Pita \& Ana Leonor Pereira 


\title{
Literatura e Medicina: alguns textos de Justo Lípsio e de dois doutores Luís Nunes ${ }^{1}$
}

\author{
ANTÓNIO GUIMARÃES PINTO²
}

\section{RESUMO:}

Pretendo neste artigo estabelecer, em primeiro lugar, a relação familiar, desatendida até hoje, que une três nomes ilustres na medicina dos séculos xVI e XVII, estabelecidos em Antuérpia, conquanto de confessa e orgulhosa origem portuguesa, e, em segundo lugar, cingindo-me ao viés literário, que é o que sobretudo me interessa, coligir e publicar alguns textos latinos do avô e neto homónimos (Luís Nunes) e duas peças epistolares de Justo Lípsio, que evidenciam a boa conta em que Álvaro Nunes e seu filho Luís eram tidos pelo prestigiado e bem conhecido polígrafo flamengo.

\section{PALAVRAS-CHAVE:}

Luís (sénior e júnior) e Álvaro Nunes; cristãos-novos; medicina e literatura; Justo Lípsio.

\begin{abstract}
:
In this article we tried to reach two main goals. On one hand, to establish the family connections between three well renowned Portuguese doctors of Hebrew ascent of $x \mathrm{VI}$ and $x \mathrm{VII}$ centuries, whose careers took place in the Flemish city of Antwerp: Luís Nunes the eldest, his son Álvaro Nunes and and his grandson Luís Nunes, whose portrait was painted by Rubens and is now at London's National Gallery. By the other hand, we present here the latin originals and Portuguese translations of some samples of the litteray legacy of the homonymous grandfather and grandson (Luís Nunes), and two letters by Justus Lipsius, that give evidence of the admiration and friendship of this prestigious Flemish author towards Álvaro Nunes and his son Luís.
\end{abstract}

\section{KEYWORDS:}

Luís (grand father and grandson) and Álvaro Nunes; Portuguese Hebrews; Medicine and Literature; Justus Lipsius

1 Este trabalho foi desenvolvido no âmbito do projecto de I\&D "Dioscórides e o Humanismo Português: os Comentários de Amato Lusitano" (http://amatolusitano.web.ua.pt) do Centro de Línguas, Literaturas e Culturas da Universidade de Aveiro, financiado por Fundos FEDER através do Programa Operacional Factores de Competitividade - COMPETE e por Fundos Nacionais através da FCT - Fundação para a Ciência e a Tecnologia, no âmbito do projecto FCOMP-01-0124-FEDER-009102.

Ao Dr. Arlindo Correia devo pronta e abundantíssima ajuda bibliográfica, sugestões pertinentes e palavras de alento que em grande parte mitigaram as forçosas limitações de quem pratica a investigação científica em pleno coração da região amazônica. Aqui publicamente se consigna a gratidão penhorada de quem tanto the deve.

2 Universidade Federal do Amazonas: aguimaraesp@gmail.com. 


\section{DE SANTARÉM A ANTUÉRPIA: TRÊS GERAÇÕES DE MÉDICOS HUMANISTAS}

No ano de 1983, em artigo intitulado “O 'Doctor Ludovicus Nonius' retratado por Rubens", ${ }^{3}$ o Professor Costa Ramalho ocupou-se, com suculenta brevidade, do percurso biográfico e literário (mais exatamente na vertente histórico-geográfica) do célebre médico luso-flamengo Luís Nunes, hoje conhecido como um dos patriarcas da dietética e, sobretudo, pelo retrato em que o imortalizou o célebre pintor seu conterrâneo, e que pode ver-se na National Gallery, de Londres. ${ }^{4}$ No sentido de determinar as raízes portuguesas do autor objeto da sua nótula erudita, Costa Ramalho colige e esmerilha uma série de textos literários e documentais que versam sobre as biografias de três médicos, de sobrenome Nunes e pertencentes a três sucessivas gerações: 1) um Luís Nunes, inequivocamente de Santarém e que floresceu na terceira, quarta e quinta décadas do século Xvi, 2) um Álvaro Nunes, largamente biografado por Barbosa Machado, 3) e um segundo Luís Nunes, retratado por Rubens, também biografado pelo abade de Sever e que as fontes impressas, sem exceção, dão como filho de Álvaro. No final do seu artigo, e perante a relativa escassez dos dados compulsados, Costa Ramalho, com a sua habitual sagacidade e sábia cautela, conclui nos termos seguintes: "Qual a relação entre este Luís Nunes 5 e o do retrato de Rubens, com quem já tem sido confundido? É difícil que não sejam parentes. Será este Luís Nunes o pai de Álvaro Nunes (Ludovici filius, no epitáfio)? Pode ser, mas não garanto. Se assim for, teremos uma linhagem de três médicos distintíssimos, verdadeiras sumidades na sua época, em que os dois mais conhecidos, e do mesmo nome, são avô e neto. Mas o parentesco não passa de hipótese."6

Procurando alicerçar com elementos mais concretos esta hipótese, e fundando-me quase exclusivamente em fontes fidedignas e coetâneas das três personalidades visadas, penso que as pesquisas que empreendi, de que resultaram os elementos que a seguir se expendem, permitem afirmar, com a segurança possível neste tipo de estudos, que de facto o Dr. Luís Nunes, natural de Santarém e residente em Antuérpia na derradeira quadra da sua vida, foi pai do Dr. Álvaro Nunes e avô do Dr. Luís Nunes, cujas vidas e atividade profissional decorreram, se não totalmente (no caso de Álvaro), pelo menos na sua grande parte, naquela cidade portuária do sul dos então chamados Países Baixos.

3 Publicado na revista Mundo da Arte 16 (Dezembro de 1983), pp. 15-18.

4 A identificação do Dr. Luís Nunes com o médico representado neste retrato de Rubens só se fez em 1950, pelo crítico de arte L. Burchard, que apontou como terminus ad quem para a pintura do quadro 1627, ano no qual o médico antuerpiense publicou a sua obra mais importante, o tratado Diaeteticon siue de re cibaria libri IV. Veja-se o artigo de Marco Romano, "Rubens e l'erma ritratto di Ippocrate. La memoria dell'antico in un ritratto di Ludovicus Nonnius", Journal of History of Collections 22.1 (2010), pp. 15-27.

5 O santareno: cronologicamente, o primeiro da série.

6 "O 'Doctor Ludovicus...", op. cit., p. 18. 
Assim, se acudirmos ao imenso repositório de informaçóes sobre médicos portugueses da primeira metade do século Xvi, que é o In Dioscoridis Anazarbei de medica materia libros quinque, de Amato Lusitano, editado pela primeira vez em 1553, ${ }^{7}$ verificamos que um Luís Nunes (ou, na forma latina, Ludovicus Nonius) aparece a dialogar com o Autor da p. 131 à 138, no decurso de três enarrationes ou comentários.

$\mathrm{Na} 1^{\mathrm{a}}$ aparição é identificado, na nota marginal, como Ludouicus Minius Sanctarensis, gralha no sobrenome que já se encontra correta na alusão que a ele se faz mais à frente, na p. 285, onde se lê a forma Nonius. É o seguinte o teor das palavras que o confrade lhe atribui:

LVDOVICVS: De iis praeceptores nostri Salmaticenses parum nos instruxere, imo eos, qui de simplicibus curam habebant, simplices appellabant.

LUÍS: Sobre este assunto os nossos professores de Salamanca pouco nos ensinaram, ou antes, chamavam 'simples' aos que se preocupavam com os símplices. ${ }^{8}$

Daqui se conclui que Luís Nunes, de Santarém, foi condiscípulo de Amato Lusitano nas aulas de medicina que este frequentou em Salamanca. Mais rico de conteúdo biográfico é o seguinte diálogo, entre Luís Nunes e Amato Lusitano, que podemos ler um par de páginas mais à frente:

LVDOVICVS: Hanc ipsam plantam quam Galenus intelligit et Dioscoridem intellexisse, scholasticis meis, cum publice Colimbriae interpretarer, saepe dixi. AMATVS: Scio certe, cum nos duo e Salmaticensi, nobili apud Hispanos gymnasio, in Lusitaniam reuerteremur, te publice medicinam apud Colimbricenses regis mandato legisse, imo ibidem tibi in eo munere primas delatas recordor. Sed ego, relicta Lusitania, ut qui, abhinc decem et octo annis, praesagieram quae nunc euenisse audio, regios contempsi honores et in Antuerpiam me recepi, ubi septennium egi, et inde illustrissimi ducis Ferrariae, Herculis secundi, iussu, Ferrariam ueni, sub cuius clientela sexennium moratus sum, ubi quoque publice artem medicam professi sumus et multa a uiris doctissimis in re anatomica et herbaria didiscimus. LVDOVICVS: Vtinam eo tempore tecum sentissem, nec in illo regno tam longam traxissem moram, ut Germanorum mores citius dinoscere potuissem, quibuscum hodie Antuerpiae felicissime deuersor.

LUÍS: Esta mesma planta, que Galeno conheceu, e eu muitas vezes, quando lecionava em Coimbra, disse aos meus alunos que Dioscórides conhecera. AMATO: Sei muito

\footnotetext{
7 Em Veneza, por Gualterus Scotus.

8 Op. cit., p. 132.
} 
bem que, quando nós os dois regressámos de Salamanca, nobre Academia na Espanha, para Portugal, tu foste lente de Medicina em Coimbra por nomeação régia, ou melhor, lembro-me de que te ofereceram no mesmo lugar uma posição vantajosa. Mas eu, depois de deixar Portugal, como alguém que há dezoito anos atrás previra aquilo que ouço que agora está a acontecer, desprezei as honrarias régias e acolhi-me a Antuérpia, onde vivi sete anos, e daí, obedecendo ao mandado do ilustríssimo duque de Ferrara, Hércules II, vim para esta cidade, permanecendo seis anos sob a sua proteção, onde também ensinei publicamente a arte médica e muito aprendi de anatomia e botânica com varóes de grande saber. LUÍS: Prouvera a Deus que nessa época tivesse pensado como tu, e não me houvesse demorado naquele reino durante tanto tempo, por forma a ter podido conhecer mais cedo os costumes das gentes germânicas, entre as quais mui venturosamente hoje vivo em Antuérpia. ${ }^{?}$

Daqui claramente se colige que Luís Nunes e Amato regressaram na mesma época de Salamanca para Portugal, donde o segundo, pouco tempo volvido, se retirou com destino a Antuérpia, tendo o primeiro permanecido durante mais alguns anos na pátria, na qual, por convite régio, desempenhou honroso cargo docente na Universidade de Coimbra. De forma mais ou menos sibilina, tanto Amato como Luís Nunes se referem aos difíceis momentos por que, na época pouco anterior à impressão do livro, e que corresponde ao tempo narrativo deste diálogo, passava a comunidade cristã-nova residente em Portugal: o primeiro, congratulando-se pela antevisão da perseguição desencadeada após a sua saída da pátria, e o segundo, lastimando por ter tardado tanto em aperceber-se da gravidade da situação, exprimindo porém este queixume sob a elegante (ou arteira) forma de reconhecer que esta tardança em desterrar-se o privara de, durante aqueles anos, gozar das delícias da hospitalidade flamenga, de que desfrutava em Antuérpia, onde "mui venturosamente hoje vivo."

Ora, para melhor estabelecermos as datas que balizam o percurso biográfico de Luís Nunes, recorde-se que Amato Lusitano abandonou Salamanca por volta do ano de 1532, permanecendo na pátria até 1534, data do seu estabelecimento em Antuérpia, três anos portanto antes de D. João III determinar a transferência da Universidade de Lisboa para Coimbra. ${ }^{10}$

9 Op. cit., p. 134.

10 Pouco depois da sua chegada a Antuérpia, para onde se deslocou a mando do mercador Henrique Pires, Amato Lusitano foi processado por permanência ilegal, em meados de outubro de 1534. Cf. António Manuel Lopes Andrade, "Ciência, Negócio e Religião: Amato Lusitano em Antuérpia", in Inês de Ornellas e CASTRO e Vanda ANASTÁCio (coord.), Revisitar os Saberes - Referências Clássicas na Cultura Portuguesa do Renascimento à Época Moderna. Lisboa, Centro de Estudos Clássicos - Faculdade de Letras da Universidade de Lisboa, 2010, pp. 9-49. 
Escutemos agora novo diálogo travado entre os dois colegas médicos, a propósito da romã e de um episódio de contornos burlescos a que deu azo o desconhecimento do latim por parte de um boticário parisiense:

LVDOVICVS: Monendi hic pharmacopolae sunt ne per malum Punicum intelligant id quod seplasiarium quidam Parisiensis intellexit, cum medicus describeret suci malorum Punicorum siue malorum granatorum, ille crassae Mineruae, hebes ingenio et ignarus uocum, cum ex malis granatis, et illis quidem optimis, sucum extractum amandare debuerat, tantum abfuit ut optima aut bona intellexerit poma ut potius putrida et corrupta acciperet, ex quibus sucum putridum extractum ad miserum aegrotantem misit, credens utique per mala, non poma, sed mala, putrida, corrupta ac flaccida granata intelligi debere. AMATVS: Abhinc decem annis rem ita euenisse audiui, imo Petrus Fernandus amicus noster, qui magna cum gloria apud Anglos Londini medicinam excercuit et nunc prospere apud Venetos agit, mihi libellum ubi haec scripta erant Antuerpiae indicauit, quae tu postea, in ea epistola quam Lexico Nebrissensis Antuerpiae excusso apposuisti, ad memoriam reuocasti.

LUÍS: Aqui convém ter-se de sobreaviso os boticários, para que não entendam por romã ${ }^{11}$ o que entendeu certo droguista parisiense, que, tendo o médico prescrito suco de romãs, ele, por boçalidade, escassa inteligência e ignorância das palavras, quando lhe cumpria aviar o suco extraído de romãs, e estas das melhores, de tal maneira deixou de entender que se tratava das boas e melhores que antes entendeu que se tratava das podres e corruptas, de que extraiu um suco fétido e podre que mandou ao mofino do doente, cuidando que devia entender-se por mala não os pomos, mas as romãs ruins, podres, estragadas e murchas. AMATO: Há dez anos atrás ouvi dizer que isso aconteceu, e até o nosso amigo Pedro Fernandes, que com grande prestígio exerceu a Medicina em Londres, na Inglaterra, e agora trabalha com êxito em Veneza, me indicou em Antuérpia o livrinho onde se contava este episódio, a que tu depois te referiste naquela carta que antepuseste ao Dicionário de Nebrija, publicado nesta cidade. ${ }^{12}$

Antes, porém, de me ocupar desta alusão à participação de Luís Nunes numa edição do Dicionário de Nebrija, vejamos a última referência que Amato Lusitano faz na sua obra

11 Em latim malum Punicum. A confusão deu-se por o inepto boticário ter confundido o substantivo malum 'pomo' com a forma neutra do adjetivo malus, $a$, um 'mau'.

12 Op. cit., p. 137. 
In Dioscoridis enarrationes ao seu colega santareno. Surge ela no comentário de Rhapontico (uulgo rheubarbo da ponto), a propósito do qual escreve:

Proinde rhaponticum hoc Graecorum diuersum a uulgari rhabarbaro esse, non solum figura, sed uiribus ipsis certissimum est. Cum autem haec litteris mandaremus, huius radicis Ponticae partem ad Antonium Musam Brasauolam, uirum doctissimum, misimus, ueluti ad Antuerpienses, ut inde singularis doctrinae uir Ludouicus Nunius, Santarenensis, Lusitanus, in Hispaniam ad amicos transmittat.

Por isso não há dúvida alguma de que este rhaponticum dos Gregos é diferente do ruibarbo comum, não só no aspeto, mas nas suas propriedades específicas. Ora, ao registar isto por escrito enviei um pedaço desta raiz do Ponto a António Musa Brasavola, varão doutíssimo, e outro para Antuérpia, a fim de que daqui o português de Santarém Luís Nunes, homem de excecional saber, o remeta para os amigos na Península Ibérica. ${ }^{13}$

Com esta afirmação ficamos certificados de que, no ano de 1553, correspondente ao da impressão da obra de Amato, Luís Nunes, se não residia com caráter permanente, pelo menos estava de alguma forma vinculado a Antuérpia. Antes de avançarmos no tempo, convirá, porém, citar a documentação referente à sua carreira académica e atuação profissional na pátria.

Ora, Sousa Viterbo e Maximiano Lemos citam e transcrevem documentos, procedentes dos arquivos universitários, passados em nome de Luís Nunes, e que o dão como regendo, na Universidade de Lisboa, Filosofia Moral, a partir de 4 de dezembro de 1529, com a categoria de substituto, e como provido em Súmulas, em 30 de outubro de 1530, sendo reconduzido por mais três anos nesta cadeira no final do triénio, por provisão datada de 16 de outubro de 1533, fazendo, durante este período de tempo, exame privado para receber o grau de doutor em medicina. ${ }^{14}$ Se alguma dúvida poderia levantar-se sobre este Luís Nunes ser o mesmo de que nos ocupamos, ${ }^{15}$ penso que ela não terá cabimento em relação à pessoa do mesmo nome que, em 17 de outubro de 1541, é nomeada, em Coimbra, lente de Terça de Medicina, ou seja,

13 Op. cit., p. 285.

14 Maximiano Lemos, "Amato Lusitano. Correcções e aditamentos. Amato Lusitano nos Países Baixos", Revista da Universidade de Coimbra 10 (1927), pp. 5-38; Sousa VITERBO, Notícia sobre alguns médicos portugueses ou que exerceram a sua profissão em Portugal. Segunda série. Lisboa, 1895, pp. 12-13. Ambos estes autores podem ver-se citados em Francisco Leitão FerReIRA, Notícias Cronológicas da Universidade de Coimbra, edição publicada, revista e anotada por Joaquim de CARVALHO, $2^{\text {a }}$ parte, volume II. Coimbra, Imprensa da Universidade, 1940, pp. 182-189.

15 Sobretudo ocasionada por Amato se referir a uma docência universitária exclusivamente conimbricense e imediatamente posterior ao regresso à pátria, numa época em que a Universidade ainda funcionava em Lisboa: o que aliás, em boa verdade, é um deslize ou lapso de memória de somenos, explicável pelo já longo desterro do médico albicastrense. 
responsável pela regência de Avicena, e que é aquela mesma a cujo cargo universitário, aparentemente prestigiante, Amato Lusitano se referira. Três anos depois, em outubro de 1544, o Dr. Luís Nunes figura na lista dos ordenados pagos pela Universidade de Coimbra, cabendolhe o montante de 70.000 réis por ano. ${ }^{16}$

Com data de 11 de junho de 1545, Luís Nunes, de Santarém, endereça, de Antuérpia, a frei Diogo de Murça, reitor da Universidade de Coimbra, uma carta-dedicatória que vemos impressa à testa de nova edição do célebre Dicionário latim-espanhol, de Élio António de Nebrija, que, naquele mês e ano, o editor Steelsius fez sair dos seus prelos antuerpienses e, conforme prometia a página de rosto:

iam denuo innumeris dictionibus locupletatum. Cui praeter omnes editiones, Auctoris eiusdem acessit Medicum Dictionarium hactenus nondum typis euulgatum, a Ludouico Nunio philosopho ac doctore Medico peritissimo, a mendarum colluuie, qua scatebat, defaecatum.

agora de novo enriquecido com inúmeras palavras e acrescentado de um dicionário médico do mesmo autor que não figurava nas ediçôes anteriores e nunca foi impresso. Limpo da enxurrada de erros, que o inundava, por Luís Nunes, filósofo e doutor em Medicina, peritíssimo.

Esta interessante carta latina foi transcrita e traduzida pelo Professor Costa Ramalho, ${ }^{17}$ e dela respiguei os passos seguintes, de interesse para o escopo biográfico que é o nosso:

Italiam profecturus dum hac iter ago [...] loci cum amplitudine, tum et nobilitate allectus, plusculis quam decreueram diebus immoratus

De viagem para Itália, ao passar por aqui (...) demorei-me mais uns dias do que antes decidira, atraído pela grandeza e pela nobreza do lugar; ${ }^{18}$

cum Salmanticae discerem inibique publice docerem no tempo em que eu estudava em Salamanca e aí mesmo ensinava; ${ }^{19}$

qua diui Hieronymi collegio insigni, cui etiam praees, e tot unum me medicum adscripseras

16 Mário Brandão, Actas dos Conselhos da Universidade de 1537 a 1557, volume I. Coimbra, Imprensa da Universidade, 1941, p. 110.

17 Latim Renascentista em Portugal. Coimbra, C. E. C. H., 1985, pp. 160-173. As traduções que apresento do título do Dicionário e desta carta introdutória da edição de 1545 são da autoria do Professor Costa Ramalho.

18 Op. cit., p. 160

19 Op. cit., p. 162. 
Ao associares-me (...) como o único médico, ao insigne colégio de S. Jerónimo de que eras e continuas a ser o presidente. ${ }^{20}$

Como se vê, tendo, aparentemente, pensado em utilizar Antuérpia como mero ponto de passagem para viagem cujo destino era a Itália, Luís Nunes, em junho de 1545 sentiu-se cativado pelas comodidades e encantos que a cidade flamenga lhe oferecia, e decidiu protelar a partida. Confirma-nos também a sua anterior passagem por Salamanca, náo só como aluno (conforme já ficáramos sabendo pelo texto dialogado inserto nas Enarrationes de Amato, atrás citado), mas igualmente como docente, e, finalmente, inteira-nos das boas relaçôes que entretivera em Coimbra com o reitor da Universidade, o ilustre hieronimita transmontano frei Diogo de Murça, relaçóes que com certeza se estreitaram pelo facto de o médico santareno prestar em exclusividade assistência clínica aos mestres e alunos do colégio universitário da Ordem religiosa a que frei Diogo pertencia.

Sou levado a pensar que, apesar da excelente impressão que Antuérpia lhe causara, Luís Nunes não assentou por então arraiais nesta cidade e decidiu tentar a sorte alhures. Se realmente chegou a rumar a Itália é algo que desconheço, mas a verdade é que parece indubitável a sua estância por alguns anos, talvez próximos dos dois lustros, em territórios de língua francesa. É que, entre janeiro e março de 1550, vêmo-lo dirigir, datada de Lausana, uma carta latina ao célebre humanista, tradutor do Novo Testamento para castelhano e reformador religioso Francisco de Enzinas, também residente em território helvético. O teor da carta, para além das gentilezas da praxe neste tipo de correspondência entre homens criados ao calor do humanismo, tem a ver sobretudo com a dificuldade em atinar com a correta nomenclatura das plantas: ao que cuido, Nunes, assoberbado com os seus afazeres médicos, promete para sazão mais desafogada os esclarecimentos relativos a dúvidas, presumo que relativas à designação vernácula para algumas plantas que punham problemas ao burgalês Enzinas, na empresa a que então se entregava de traduzir as Escrituras para a sua língua. ${ }^{21}$

Mais documentada nos aparece a sua estadia em França, ao serviço da rainha Catarina de Médicis, esposa de Henrique II. De facto, além do testemunho que constitui a carta-prefácio à $2^{a}$ edição antuerpiense do Dicionário de Nebrija, de 1553, que publico e traduzo neste artigo, que Luís Nunes escreveu 'no seu 'escritório de Paris', Andrés Laguna, na nota explicativa dirigida "Al benigno lector", que podemos ler no fl. Iiii vo do seu Dioscorides, saído dos prelos de Iuan Latio, de Antuérpia, no ano de 1555, informa: "Ayudaronme opportunamente para

20 Op. cit., p. 170.

21 Esta carta pode ver-se transcrita e traduzida para espanhol em Epistolario de Francisco de Enzinas. Texto latino, traducción española y notas de Ignacio J. García PINILLA. Genebra, Librairie Droz, 1995, pp. 508-511. O tradutor e anotador desta carta afirma, não sei com que base documental, que Nunes "se encontraba asentado en Lausana desde años antes." 
el tal negocio con muchos nombres Portugueses, de los quales yo no tenia entera noticia, El Doctor Luys Nuñez, Excellente Medico de la Serenissima Reyna de Francia: y Varon raro de nuestros tiempos."

Esta informação, em que parece fazer-se referência a um cargo que Nunes então ainda desempenhava, é corroborada e ampliada pelo passo seguinte de uma carta que o embaixador Francisco Pereira escreveu, de Bruxelas, ao rei D. João III, com data de 11 de novembro de 1558: "A rainha de Ingraterra está melhor das suas terçãs, como tenho escrito a Vossa Alteza, e per cima disto el-rei mandou agora o doutor Luís Nunes, português, que está assentado em Enveés, que cá tem nome de grandíssimo físico, e já de Paris veo com este nome, onde esteve alguns anos quando saiu desse reino." 22

Convém esclarecer que, apesar das melhoras aqui anunciadas, a rainha de Inglaterra, Maria Tudor, morreu a 17 de novembro de 1558, no palácio de St. James, em Londres, em consequência de uma epidemia de gripe, aqui designada por "terçãs", e que o 'rei' aludido na carta de Francisco Pereira é o então rei-consorte de Inglaterra, Filipe, em breve Filipe II de Espanha, que se encontrava nessa ocasiāo nos Países Baixos, donde, pelos vistos, enviou a Inglaterra o Dr. Luís Nunes para tratar da sua esposa: sem êxito, como os factos demonstraram. Também ficamos certificados de que em 1558 o Dr. Luís Nunes já estava “assentado” em Anvers (ou Antuérpia), cidade onde deve ter morrido em data que ignoramos.

Tal desconhecimento não se verifica com seu filho, o Dr. Álvaro Nunes, cujo epitáfio nos foi transmitido pelo seu contemporâneo Laurentius Beyerlinck, na obra Opus Chronographicum orbis uniuersi ab anno 1572 usque ad annum 1611, Antuerpiae, ex typographeio Hieronymi Verdussii, 1611. Com efeito, na secção consagrada aos varôes ilustres falecidos em 1603 nos Países Baixos, o antuerpiense Beyerlinck escreve o seguinte:

\begin{abstract}
Venio ad Aluarum Nonnium [...] magno in pretio apud magnos semper habitus et principum nostrorum archiater assiduus fuit. Bibliothecam habuit diuite librorum supellectile instructam, quam Ludouico Nonnio filio reliquit, qui, patriis uestigiis inhaerens, eruditionis merito Medicinae etiam lauream consecutus, uarios aliarum insuper scientiarum thesauros sibi comparauit. Sed et optimum parentem funeris tumulique pio honore affecit et ad D. Iacobi Antuerpiae (qua in urbe olim ille floruit) conditum, aeterno hoc elogio inter mortales aeternum superesse uoluit:
\end{abstract}

Vou agora ocupar-me de Álvaro Nunes (...) sempre tido em grande conta pelos grandes e que foi médico assistente dos nossos príncipes. Possuiu uma biblioteca ricamente ataviada de livros, que deixou a seu filho Luís Nunes, o qual, seguindo as pisadas de seu pai, depois

22 Apud Notícias cronológicas da Universidade de Coimbra, op. cit., p. 183. 
de merecidamente alcançar renome como médico e erudito, além disso enricou-se com os diversificados tesouros de outros saberes. Mas também como bom filho honrou o excelente pai com o funeral e o túmulo e, sepultando-o na igreja de S. Tiago, em Antuérpia (cidade na qual outrora brilhara) quis, mediante o seguinte eterno elogio, que eternamente ele sobrevivesse entre os mortais: ${ }^{23}$

Ora, curiosamente, é só bem mais à frente, na p. 294, que pode ver-se transcrito este epitáfio latino, que Barbosa Machado reproduz com exação da obra de Beyerlinck na entrada consagrada a Álvaro Nunes, e que damos em tradução de Américo da Costa Ramalho: "A Álvaro Nunes, filho de Luís, / De 60 anos de idade, falecido a 9 de dezembro de 1603, / Filósofo e médico da corte, / Ilustre por cultura e virtude, / Caro aos magnates. / A sua gentileza usou-a com todos, / Ele para quem nada foi mais caro na vida, do que dá-la aos outros, / Nada na morte mais agradável, que passar a uma vida melhor. / Mandaram colocar muito merecidamente (esta lápide) / a Mulher ao marido, os filhos ao pai." ${ }^{24}$ Convém referir que, no texto original, o numeral 60 está escrito em letras romanas, pelo que não será de descartar a possibilidade, mais verosímil para este tipo de numeração, de ter escapado alguma(s) letra(s), por exemplo um (ou dois) $X$. Parece militar a favor desta suposiçáo uma excelente gravura, da autoria do artista de Antuérpia Jan Wierix (1549-c.1618), de que existem exemplares nas coleçóes de vários museus (por exemplo, no Prentenkabinet do Museu Boimans van Beuningen, de Roterdão), e que representa, conforme reza a epígrafe: ALVARVS NONIVS LVDOI. F. H. N. ["Álvaro Nunes, filho de Luís"], a qual igualmente nos informa do ano em que o retrato foi executado: 1586. Além do nome do gravador (Johannis Wieriecx fecit), no lado esquerdo da legenda vê-se um brasão, com paquife e elmo encimado por cabeça de serpente, no qual se representa parte de antebraço, saindo de manga tufada, e uma mão segurando um livro. O retrato, aberto a buril, reproduz a cabeça e a parte superior do tronco de um homem de tipo mediterrânico, usando barba e bigode, com idade que acho poder estimar-se, sem grande margem de erro, entre os cinquenta e os sessenta anos, e que portanto orçaria a casa dos setenta à data do óbito.

23 Op. cit. no corpo do texto, p. 272.

24 Américo da Costa Ramalho, "O 'Doctor Ludovicus...", op. cit., p. 15. 


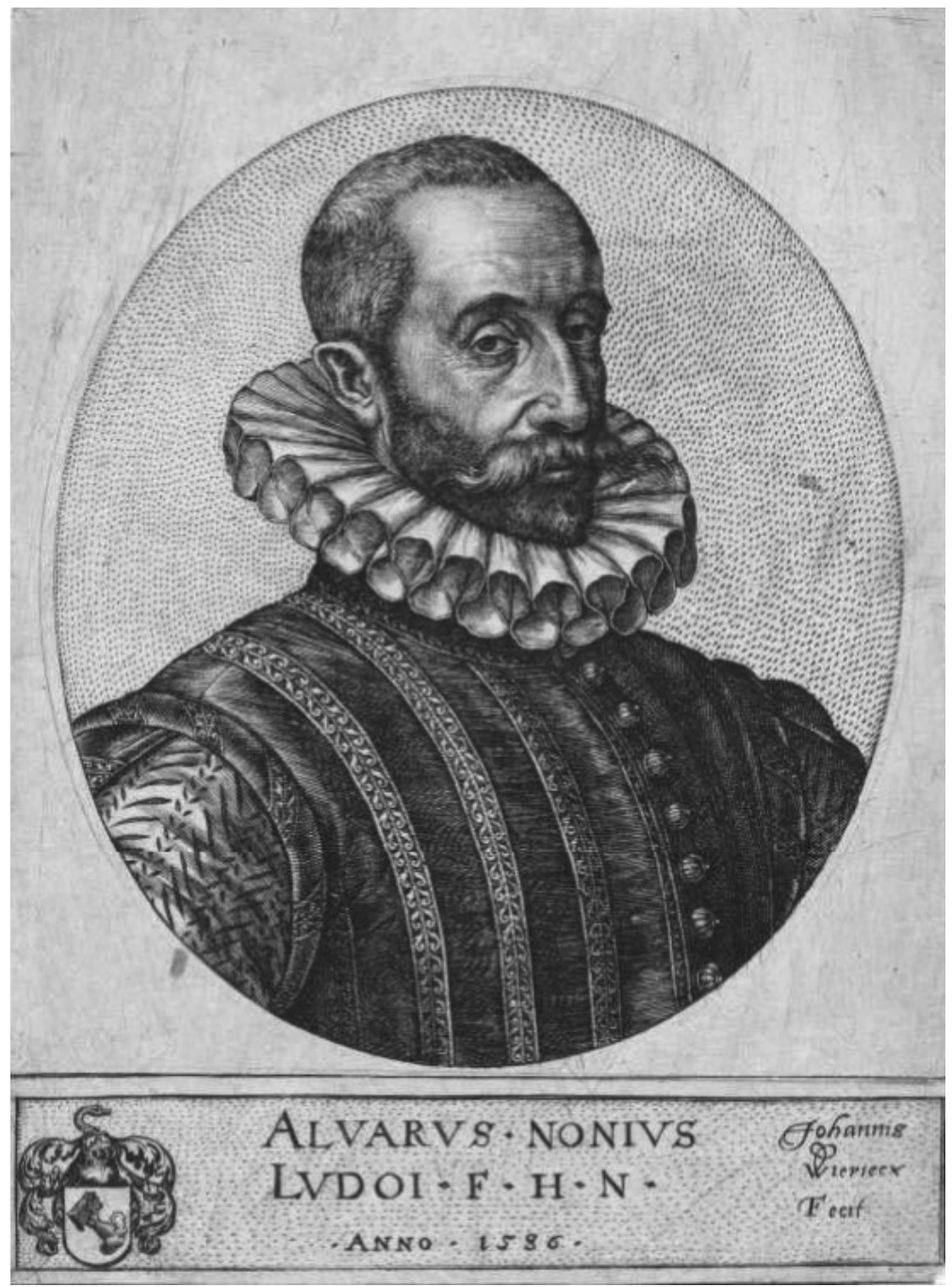

Figura 1 - O Dr. Álvaro Nunes. Gravura de Jan Wierix

Mais me corroboram na convicção de que se encontra mal transcrita por Beyerlinck a idade de Álvaro Nunes à data da sua morte as palavras que lhe consagra Benedito Arias Montano, no livro em que o nosso médico deixou o seu único legado científico-literário, as quais fazem supor um homem maduro que, em 1573, já estaria longe dos trinta que teríamos de atribuir-lhe, no caso de aceitarmos como corretos os sessenta em romano da inscrição transcrita no Opus Chronographicum. Com efeito, o célebre editor de Antuérpia, Cristóvão Plantino, entregou à luz 
da publicidade, no ano de $1574,{ }^{25}$ uma obra intitulada De recta curandorum unlnerum ratione et alii eius artis praeceptis libri II, da autoria do médico-cirurgião espanhol Francisco Arceo, na qual, da p. 3 à 11, podemos ler uma Prefação, da autoria de Benedito Arias Montano, escrita em Antuérpia, a 22 de abril de 1573, e onde o conhecidíssimo biblista, ademais de fazer a calorosa apresentação do autor, tal como ele natural de Fregenal de la Sierra, na atual província de Badajoz, se refere também nos termos seguintes ao Dr. Álvaro Nunes:

[8] Vt autem opus non sine digno ornamento, quamquam genio ipso suo ornatissimum esset, tamen cultius prodiret in publicum, uoluit doctissimus ac mihi suauissimus amicus Aluarus Nonnius, Hispanus, qui Antuerpiae litterarum ac disciplinarum uariarum studiis ingeniosissimam dat operam ac medicinam cum aegrotantium usu exercet, alteram partem, chirurgicam uidelicet, breuibus atque eruditis annotationibus illustrare, ut [9] ostenderet quam apte quamque diligenter antiquorum medicorum doctrinam Arcaeus noster persequatur [...].

ora, a fim de que esta obra não saísse a lume desprovida do merecido atavio, conquanto já por sua própria natureza estivesse muitíssimo bem ataviada, mesmo assim para que surdisse ainda mais elegante, quis o mui douto e meu prezadíssimo amigo Álvaro Nunes, hispânico, que em Antuérpia se dedica com imenso talento a estudos de letras e de variadas ciências e exerce a medicina com proveito dos doentes, ornamentar com breves e eruditas anotaçôes a primeira parte, ou seja, a consagrada à cirurgia, por forma a [9] mostrar o quão competente e desveladamente o meu conterrâneo Arceo segue os ensinamentos dos médicos da Antiguidade (...).

Logo depois deste texto preambular, da p. 12 até à p. 16 encontra-se uma carta com o seguinte cabeçalho: Ad Benedictum Ariam Montanum, theologum celeberrimum, Aluarus Nonnius. ["Álvaro Nunes ao mui afamado teólogo Benedito Arias Montano”], que infelizmente não encerra quaisquer achegas autobiográficas que aqui nos interessem, o mesmo sucedendo com as anotações médicas, ${ }^{26}$ às quais Arias se referira e que se apresentam no final dos capítulos da parte do livro consagrada à cirurgia (até à p. 210).

25 Conquanto no colofão se leia: pridie nonas Nouembris, anno Domini 1573.

26 Estas cartas proemiais, assim como todo o livro, foram recentemente publicados e traduzidos para espanhol em edição da responsabilidade de Andrés Oyola FABIÁn e José Miguel CoBos Bueno: Francisco ARCEO, Método verdadero de curar las heridas. Huelva, Servicio de Publicaciones de la Universidad de Huelva, 2009. Com o desplante habitual nos autores espanhóis (no caso vertente, supostamente versados em língua latina), os tradutores-comentadores expeditamente transformaram em 'espanhol' o Álvaro Nunes, que Arias Montano genérica e corretamente designara por 'hispânico' (hispanus). 
Finalmente, Florbela Veiga Frade, na sua dissertação de doutoramento, ${ }^{27}$ fundada em documentação original existente nos arquivos portugueses e flamengos, mostrou-nos a plena integração e posição de relevo do Dr. Álvaro Nunes dentro da nação ou comunidade portuguesa de Antuérpia. De facto, em 1571 e 1572 o seu nome consta da lista dos portugueses que residiam com suas famílias em Antuérpia; ${ }^{28}$ em 1584 vêmo-lo a gerir, de parceria com Rodrigo da Veiga, de Évora, o consulado português; ${ }^{29}$ consignando, enfim, um registo de 1591, que a assistência médica aos portugueses mais pobres era por ele assegurada.

Sabendo nós que o Dr. Álvaro faleceu em 1603, penso não haver dúvidas de que o Dr. Nunes que faz parte de uma lista, datada de 1604 e publicada pela investigadora que estamos a seguir, com os nomes dos membros da comunidade portuguesa residente em Antuérpia, ${ }^{30}$ não pode ser outro senão seu filho Luís, que já aparece com o título e nome completo num rol com as mesmas características do ano de 1611: ${ }^{31}$ com o que nos vemos chegados ao membro mais jovem e conspícuo desta ilustre família de médicos humanistas. No entanto, antes de prosseguirmos com a biografia do filho, cabe a pergunta sobre o lugar onde o pai veio ao mundo e a Universidade em que adquiriu tão grande e unanimemente reconhecido saber médico. Nada de concreto consegui apurar, e as afirmaçôes anacrónicas e infundamentadas de alguns escritores nem sequer merecem o trabalho da refutação. Ora, se atentarmos no que ficou dito sobre a vida mais ou menos errante do pai (designemo-lo por Luís Nunes 'Sénior') e a idade presumível do filho, penso não ser muito arriscado supor que o seu nascimento se deu em terras lusitanas e, quem sabe, em Lisboa, ${ }^{32}$ em cuja Universidade tudo indica que o Dr. Luís Nunes ensinou na década de 30 do século xvi. Podemos também conjeturar, no domínio da especulação, que tenha acompanhado o pai quando este abandonou a pátria e, se não ficou logo em Antuérpia ao cuidado de familiares ou amigos, não é inverosímil que tenha estanciado em terras de França e aí estudado Medicina. É também possível que seja ele o Alvarus Novius Lusitanus cuja inscrição se encontra consignada no registo de matrículas da Universidade de Lovaina com a data de 28 de agosto de 1560, mas a inexistência nos arquivos desta Universidade de quaisquer outras informaçóes curriculares ou pessoais deixa-nos a dúvida,

27 As relações económicas e sociais das comunidades sefarditas portuguesas. O trato e a família: 1532-1632, tese de doutoramento em História Moderna apresentada à Faculdade de Letras da Universidade de Lisboa, 2006 (policopiada).

Op. cit., pp. 369 e 371.

29 Op. cit., p. 279.

30 Op. cit., p. 375.

31 Op. cit., p. 377.

32 Berço que de resto Barbosa Machado the dá, para logo em seguida falhar de modo estrondoso ao afirmar que o Dr. Álvaro veio de Lisboa para os Países Baixos acompanhando como médico o arquiduque Alberto, que, conforme se sabe, entrou pela $1^{a}$ vez em Bruxelas em fevereiro de 1596: ou seja, Álvaro Nunes, na melhor das hipóteses, só teria vivido em Antuérpia os derradeiros sete anos da sua vida... 
não apenas sobre se se trata da mesma pessoa, como também sobre a existência anterior de quaisquer titulações ou preparo académico. ${ }^{33}$

Sendo meu desígnio, na primeira parte deste artigo, de cariz mais histórico, como no começo ficou declarado, apenas estabelecer os laços de parentesco e a linhagem lusitana dos três médicos de sobrenome Nunes cuja vida e carreira se encontram também fortemente ligadas à cidade de Antuérpia, no caso do Dr. Luís Nunes 'Júnior' (nomeemo-lo assim para destrinçá-lo do avô homónimo) bastar-nos-á apontar os dados essenciais da sua biografia e coligir uma ou outra notícia, veiculada por autores seus contemporâneos, atinente aos aspetos que especificamente aqui me importam. Ora, a unanimidade dos autores mais recentes que do Dr. Luís Nunes se ocuparam estão acordes em relação aos seguintes dados biográficos: ${ }^{34}$ nasceu em Antuérpia em 1553, graduou-se em Medicina em Lovaina, em torno de 1577, e morreu na cidade natal com 92 anos, portanto em $1645 .{ }^{35}$

Quanto às referências de coetâneos e conterrâneos, em 1623 o professor do Colégio Trilingue, de Lovaina, Valerius Andreas, autor de um dicionário de autores naturais dos Países Baixos, assim lhe traça o perfil humano e intelectual

Ludouicus Nonnius, Aluari, medici Lusitani, filius, Antuerpiae natus, medicus, et ipse excellens, historicus, poeta. In singulis ostendit ingenii praestantiam, uariam doctrinam, antiquitatis notitiam non uulgarem. Ad haec, tractabilis et comis moribus: talem certe fatentur qui praesentem absentemque norunt aliquando. Scripsit hactenus:

Luís Nunes, filho do médico português Álvaro, natural de Antuérpia, médico, e como tal excelente, historiador e poeta. Em cada uma destas áreas mostra superior inteligência, saber variegado e um conhecimento incomum da antiguidade. Além disso, simpático e

33 Veja-se Arnold H. Schillings, Matricule de l'Université de Louvain, IV (1528-1569). Bruxelas, 1963, p. 606. Curiosamente, entre todos os estudantes matriculados entre 1545 e 1560, o outro único de nome próprio Álvaro que se nos depara, é um Alvarus Almaras, inscrito em 13 de agosto de 1554 , identificado como Antuerpiensis, ou seja, como natural da cidade onde o nosso compatriota constituiu família e desenvolveu toda a sua atividade profissional.

34 Nomeadamente os seguintes, que, a despeito de aqui e além claudicarem (sobretudo quando se referem a realidades ou nomes portugueses), nos pareceram mais bem informados: Leonard Jan BRUCE-ChwATt, "Ludovicus Nonnius, M. D., 1553-1645", Bulletin of the New York Academy of Medicine 60.9 (November 1984), pp. 938-943; A. R. FERRAZ, "The Portuguese background of Ludovicus Nonnius", Derde Symposium Geschiedenis der geneeskundige wetenschappen. Nonius en de 'dietetiek'. 2 december 1995. Academia Regia Belgica medicinae - Dissertationes - Series Historica, 5. Bruxelas, Kon. Akademie voor Geneeskunde, 1996, pp. 55-66; Hans PoHL, Die Portugiesen in Antwerpen, 1567-1648: zur geschichte einer Minderheit. Wiesbaden, Franz Steiner, 1977, pp. 108-109; Jean-Pierre TRICOT, Ludovicus Nonnius (1553-1645): humanistisch geneesheer, grondleger van de medische dietetiek. Beveren, Herman Cols, 1984.

35 De facto, a dedicatória que o autor escreveu para a $2^{a}$ edição do Diaeteticon, editada em Antuérpia, apud Petrum Bellerum, está datada pridie Idus Maiis 1645. 
de trato afável, como certamente confessam os que alguma vez o conheceram, ou diretamente ou de outiva. Escreveu até hoje:" segue-se a relação das obras publicadas até à data. ${ }^{36}$

A edição do mesmo livro, publicada em 1643, impressa também em Lovaina por Iacobus Zegers, na entrada correspondente a Luís Nunes, nas pp. 636-637, apresenta um texto idêntico, acrescentando apenas, às obras publicadas até entâo, o Diaeteticon, que saíra a lume em 1626. Dois anos depois, em 1628, o antuerpiense Franciscus Sweertius publica, na sua cidade natal e apud Guglielmum a Tungris, uma obra com o mesmo desígnio da acabada de citar, e sob a qual se lançou a acusaçáo de havê-la plagiado, intitulada Athenae Belgicae siue Nomenclator inferioris Germaniae scriptorum, na qual, nas páginas 521 e 522, se pode ler o seguinte:

Ludouicus Nonius, Aluari medici Lusitani filius, natus Antuerpiae, mihi a longo tempore, medicus elegans, poeta clarus, antiquarius sollers, utriusque linguae peritissimus, comis moribus

Luís Nunes, filho do médico português Álvaro, nascido em Antuérpia, meu íntimo amigo de longa data, médico distinto, poeta ilustre, perspicaz investigador de antiguidades, conhecedor a fundo do latim e do grego, de trato afável.

Enumerava em seguida as obras publicadas até então, acrescentando: Breui daturus: Elogia Hispanorum armis illustris, ["Em breve dará a lume Elogios de hispânicos ilustres na guerra"] obra esta que, ao que me foi possivel averiguar, nunca saiu à luz pública, pelo que o espólio literário de facto publicado por Luís Nunes 'Júnior' é aquele que o leitor interessado poderá encontrar minuciosamente descrito por Barbosa Machado.

\section{LITERATURA E MEDICINA: ORIGEM DOS NOSSOS TEXTOS}

Transcrevi e traduzi do latim cinco textos a que, segundo penso, a epígrafe 'Literatura e Medicina' assenta na perfeição. De facto, a carta-dedicatória a frei Diogo de Murça, do santareno Luís Nunes, é uma boa amostra das boas avenças que era possível existirem, e amiúde se davam no século Xvi, entre a medicina e o conhecimento das culturas e línguas grega e latina. Quanto às duas cartas de Justo Lípsio, endereçadas, uma a Álvaro Nunes, e a outra a seu filho Luís, pela sua qualidade intrínseca, que é a que seria de esperar por virem da pena de um dos maiores escritores em latim da segunda metade do século XVI, merecem o nosso apreço

36 Bibliotheca Belgica. Lovanii, apud Henricum Hastenium, 1623, p. 584. 
de amantes da boa latinidade, mas interessam-nos sobretudo por terem como destinatários dois médicos ilustres que nunca renegaram a sua origem portuguesa. Finalmente, no caso dos dois poemas de Luís Nunes 'Júnior', o próprio género escolhido pelo autor é índice inequívoco dos propósitos e pendores literários deste médico multifacetado, hoje sobretudo lembrado como um dos pioneiros da dietética.

1. A Carta-dedicatória a frei Diogo de Murça ocupa os fólios Aij-Aiij do Dictionarium latinohispanicum, et uice uersa hispanicolatinum, Aelio Antonio Nebrissensi interprete, nunc denuo ingenti uocum accessione locupletatum pristinoque nitori, sublata mendarum colluuie, Ioannis Belleri ope ac studio restitutum. Ad haec, Dictionarium propriorum nominum ex probatissimis Graecae et Latinae linguae auctoribus, addita ad calcem neoterica locorum appellatione concinnatum, Antuerpiae, in aedibus Ioannis Steelsius, 1553, longo título que, em vernáculo lusitano, quer dizer: "Dicionário de latim-espanhol e, vice-versa, de espanhol-latim, da autoria de Élio António de Nebrija, agora de novo enriquecido com um acréscimo de imensas palavras e, depois de alimpado da enxurrada de erros, restituído ao seu original primor graças ao desvelo e trabalho de João Bellerus. Além disso, aditou-se um dicionário de nomes próprios, a partir dos mais aprovados autores das línguas grega e latina, a que se ajuntaram no final as modernas designaçôes dos lugares. Em Antuérpia, nas oficinas de João Steelsius, 1554.”

Conforme atrás se disse, Luís Nunes no ano de 1545 já introduzira esta mesma obra e a colocara sob a proteção de frei Diogo de Murça, a quem se dirige de novo com o mesmo desígnio, informando do mesmo passo que esta nova edição se apresenta significativamente melhorada em relação à anterior. Como o leitor poderá verificar, neste breve escrito o autor revela-se um verdadeiro médico-humanista, em quem o conhecimento das línguas e autores greco-latinos vai de par com uma consciência aguda das responsabilidades sociais, no sentido da ampla difusão do saber, que impendem sobre o intelectual probo. Para cumprir com este imperativo ético escreve Nunes - , cumpre dar de mão a pequenas vaidades e orgulhos mundanos, proclives a ver com olho crítico e comentar com língua malédica o facto de um médico de renome perder o seu tempo com coisa aparentemente tão de somenos, como seja patrocinar e colaborar na edição melhorada de um dicionário.

2. A breve e elegantíssima carta que Justo Lípsio dirigiu, de Liège e com data de 24 de junho de 1592, ao Dr. Álvaro Nunes, faz parte do imenso espólio epistolar daquele polifacetado e conhecidíssimo polígrafo flamengo, e encontra-se impressa em Iusti Lipsii epistolarum selectarum centuria tertia ad Belgas, Antuerpiae, ex officina Plantiniana apud Ioannem Moretum, 1602. ["Terceira centúria de cartas seletas de Justo Lipsío, dirigidas a pessoas originárias dos Países Baixos, em Antuérpia, da oficina de Plantino, na casa de João Moretus”] Colige-se da leitura desta missiva que o Dr. Álvaro Nunes interviera como medianeiro do grão-duque da Toscana, 
que pretenderia estender a sua asa mecenática, e com certeza ter junto de si em Florença, o prestigiado homem de letras flamengo, que elegantemente se escusa, alegando motivos de saúde. O tom da carta e a referência a contactos pessoais, aquando de uma anterior visita de Lípsio a Antuérpia, legitimam a nossa convicção de que, à semelhança do pai e do filho, o Dr. Álvaro Nunes era, além de excelente médico, homem de pendores literários, como aliás já atrás vimos, ao citarmos os testemunhos de Arias Montano ("dedica-se com imenso talento a estudos de letras") e do cónego Beyerlinck ("possuiu uma biblioteca ricamente ataviada de livros”).

3. A carta que Justo Lípsio escreveu e remeteu de Lovaina, a 21 de setembro de 1604 , ao Dr. Luís Nunes 'Júnior', pode ver-se na página 5 do livro Iusti Lipsii epistolarum selectarum centuria quinta. Miscellanea postuma, Antuerpiae, ex officina Plantiniana apud Ioannem Moretum, 1607. ["Quinta centúria de cartas seletas de Justo Lipsío. Póstuma, a diversos destinatários, Em Antuérpia, da oficina de Plantino, na casa de João Moretus"] Trata-se de uma carta de conteúdo quase exclusivamente histórico-literário, na qual um dos homens do século XVI mais eruditos em história e cultura clássicas trata de igual para igual e se louva no discernimento e profundo saber do médico luso-flamengo. Forram-nos de aqui tecer mais comentários as anotaçóes que fizemos à carta de Lípsio e mediante as quais - através da transcrição de passos pertinentes do epítome histórico-geográfico de Nunes intitulado Hispania, pela primeira vez publicado em 1607 — ficará bem patente a profunda ciência e sólida independência de juízo do patriarca da dietética.

4. Em 1603 publica Rodrigo de Castro, célebre médico português residente na Alemanha, um tratado geral de ginecologia, o qual, entre as peças poéticas laudatórias, que era então da praxe colocar no início dos livros, nos apresenta um engenhoso poema, bem lardeado de saber clássico, da autoria de Ludouicus Nonius, e no qual este doctor medicus, Lusitanus, pede para a fronte do colega e compatriota ${ }^{37}$ os lauréis de uma eterna e merecida glória. Embora as bibliografias deem a $1^{a}$ edição deste livro como publicada em Hamburgo, ex Officina Frobeniana, typis Philippi Ohr, o exemplar de que me servi na página de rosto não indica qualquer nome de impressor ou editor, informando apenas que a obra se imprimiu cum gratia et privilegio Caesareae Maiestatis ["com autorização e privilégio do imperador”], Coloniae ["em Colónia”]. Os nove dísticos elegíacos que compóem a homenagem poética de Nunes encontram-se na p. 3 da obra, cujo longo título se inicia do seguinte modo: Roderici a Castro, Lusitani, philosophiae ac medicinae doctoris per Europam notissimi, de uniuersa mulierum medicina. ["Tratado geral

37 Embora presumivelmente nunca tenha saído dos Países Baixos, onde nasceu, o Dr. Luís Nunes, na sua qualidade de integrante da comunidade lusa de Antuérpia, considerava a nacionalidade portuguesa como a sua: estatuto que de modo algum lhe contestaremos. 
de ginecologia, por Rodrigo de Castro, português, doutor em medicina e filosofia, muitíssimo conhecido por toda a Europa"]

5. A obra mais suculenta e de propósitos mais evidentemente literários do conjunto que ofereço ao leitor é o epicédio ou poema fúnebre com o qual a musa do Dr. Luís Nunes pranteou o decesso do seu amigo Justo Lípsio, falecido em 23 de março de 1606, com 59 anos incompletos. Ocupa as páginas 52 a 56 de um volume, com 114 páginas numeradas, in memoriam do literato flamengo desaparecido. Integram-no apenas composições poéticas em latim e grego (estas em reduzido número) e leva por título Iusti Lipsii sapientiae et litterarum antistitis fama postuma, Antuerpiae, ex officina Plantiniana apud Ioannem Moretum, 1607. ["Fama póstuma de Justo Lípsio, mestre da sabedoria e das letras. Em Antuérpia, da oficina de Plantino, na casa de João Moreto, 1607"] Uma outra edição deste epicédio publicou-se em 1614, podendo ler-se, com o título de In Lipsii obitum, entre as páginas 695 e 698 da coletânea intitulada Deliciae c. poetarum Belgicorum, huius superiorisque aeui, tertia pars, collectore Ranutio Ghero. Francofurti, Tipis Nicolai Hoffmanni, sumptibus Iacobi Fischeri, anno MDCXIV. ["Primores dos poetas dos Países Baixos, de hoje e do passado, terceira parte, coligidos por Ranutius Gherus. Em Francoforte, às custas de Iacobus Fischerus e impresso por Iacobus Fischerus"] Neste mesmo florilégio e imediatamente antes do poema aqui traduzido pode ler-se, entre as páginas 693 e 695, outra amostra da inspiração poética, neste caso epitalâmica, do nosso autor, escrito in nuptias Ioan. Wouerii. ["para as bodas de João Woverus"]

Quanto à elegia dedicada a Lípsio, como o leitor poderá confirmar, Luís Nunes conseguiu apresentar nela um conspecto das mais significativas obras em que o homenageado revelou o seu imenso saber clássico, inteligentemente citadas mediante alusôes que revelam também o à-vontade com que o médico luso-flamengo se movia nos domínios da cultura greco-latina. Não descurou tão-pouco a vertente ética e religiosa que Justo Lípsio cultivou com especial afinco, e até devoção, sobretudo na parte final da sua vida. 
TEXTOS

E TRADUÇÕES 
Dictionarium latinohispanicum, et uice uersa hispanicolatinum, Aelio Antonio Nebrissensi interprete, nunc denuo ingenti uocum accessione locupletatum pristinoque nitori, sublata mendarum colluuie, Ioannis Belleri ope ac studio restitutum. Ad haec, Dictionarium propriorum nominum ex probatissimis Graecae et Latinae linguae auctoribus, addita ad calcem neoterica locorum appellatione concinnatum, Antuerpiae, in aedibus Ioannis Steelsii, 1553

\section{[Aij]}

Optimo ac religioso uiro fratri Iacobo a Murça, Diuinarum Litterarum doctori clarissimo et Conimbricensis Academiae moderatori uigilantissimo, Ludouicus Nonius, a Sanctarena, medicae artis professor felicitatem

Cum superioribus annis, praesul amplissime, Antonii Lexicon in lucem esset proditurum, quibus ego causis impulsus illud tuae humanitati dedicandum existimauerim, facile, ut coniicio, ex nostra praefatione intelligere potuisti. Et, quamquam iam tum apud me satis erat constitutum nullum posthac eius generis librum, quantumlibet doctum et erudite conscriptum, cuiusquam patrocinio commendare, quippe qui essem expertus multos nominis mei studiosos iniquo animo tulisse me (a quo aliquid potius in re medica in dies exspectabant, quod illorum de studiis meis opinioni responderet) in id tempus insumere, quod nec hanc aetatem deceret, nec dignitati iam nostrae conueniret: cogebar tamen, Pater spectatissime, iure optimo hanc animi mei sententiam, tum ob publicum studiosorum commodum, tum etiam ob rei ipsius honestatem, mutare nec in proposito susceptoque consilio diutius permanere. Illa enim duo cum sint quae frugi hominem et probum ad omnem uitae actionem dirigere debeant, et quibus de omnibus quae fiunt ratio probabilis ostendi atque exponi possit, ubi me duplici illa ratione ad id officii genus adductum ostendero, amicis, ut arbitror, faciam satis, nec improborum hominum iudicia incurram.

Cum enim qui litterarum studiis fauent et earum studiosis prodesse cupiunt nihil praetermittere debeant quod e re ipsorum esse intelligant, etiamsi a grauioribus studiis aliquantulum ferientur, non uideo cur officium in Antonii Dictionario expoliendo, augendo et locupletando uitio dari cuiquam debeat, in praestantiore disciplina quamlibet uersato. Hic siquidem liber in tanto pretio ac existimatione, postquam semel in lucem editus est, apud Hispanos est habitus ut $\left[\mathbf{v}^{\mathbf{o}}\right]$ docti ad unum omnes ei non deteriorem locum in suis 


\section{[Aij]}

Ao excelente e piedoso varão frei Diogo de Murça, mui ilustre doutor em Sagrada Teologia e vigilantíssimo Reitor da Universidade de Coimbra, Luís Nunes, de Santarém, professor de Medicina, envia votos de felicidade

Quando, digníssimo Reitor, em anos recentes estava a ponto de ser publicado o Dicionário de António, eu, movido por certas razóes, pensei que deveria dedicá-lo à tua afabilidade, consoante conjeturo que facilmente pudeste entender pelo meu prefácio. E, embora já então eu tivesse firmemente decidido que a partir desse momento não recomendaria à proteção fosse de quem fosse nenhum livro deste género, por mais douto e eruditamente que tivesse sido escrito, visto como tinha experimentado que muitas pessoas que prezavam o meu prestígio suportavam de muito mau talante que eu (de quem de dia para dia estavam à espera de algo mais ligado com a Medicina que correspondesse à opiniáo deles acerca dos meus estudos) empregasse nisso o meu tempo: algo que nem ficava bem à minha idade nem quadrava já à minha posição, todavia, prezado Padre, sentiame obrigado a, com o melhor dos motivos, mudar esta opinião do meu espírito - não só por amor do proveito público dos estudiosos, mas também devido à bondade da própria coisa - e a não me manter fiel por mais tempo à decisão que me propusera e assumira. É que, sendo aqueles dois os critérios que devem dirigir o homem reto e probo em relação a todos os atos da vida, e com os quais se pode apresentar e dar a conhecer a razão provável de tudo que se faz, quando mostrar que esse duplo motivo me levou a cumprir tal espécie de dever, por um lado, segundo penso, terei satisfeito aos amigos, e por outro não me exporei aos juízos dos homens ruins.

De facto, uma vez que os que favorecem os estudos literários e vivamente almejam ser úteis aos estudiosos dos mesmos, não devem negligenciar nada daquilo que entenderem que é vantajoso para estes, ainda que repoisem algum tanto de estudos mais sérios, náo vejo por que motivo deva considerar-se como censurável o serviço prestado por alguém, por muito versado que seja em saberes mais alevantados, em acepilhar, acrescentar e enricar o Dicionário de António. Visto que este livro, desde a primeira vez que saiu a lume, é tão estimado e reputado entre os povos da Hispânia que [vo 
bibliothecis dederint. Quotus enim quisque doctorum apud eos est qui, nisi sit omnium ingratissimis, iis Antonii uigiliis non multum se fateatur adiutum et a graui quasi sopore excitatum? Quis non uidet post editum hoc Antonii opus apud nationes alias doctos homines auctorem hunc uehementer secutos, Dictionaria Latinogallica et Latinogermanica accurate etiam scripsisse? Nec umquam laborem hunc sponte subiissent nisi et auctoris nostri consilium multum probassent, et litteris litteratisque omnibus uberem fructum messuros se intellexissent.

Verum, cum abhinc annos septem tuis auspiciis Dictionarium hoc in publicum iret, dolui non potuisse me naeuos aliquot, qui iam impressi atque etiam inusti esse uidebantur, delere, nec item uoces multas, quae adiici possent, quod ad litteram $O$ liber iam typis esset excusus, addere. Namque eam libri partem uoculae nonnullae, candorem Latium minus referentes, foedauerant et Arabica plurima, leuem fortasse aliquem usum barbaris medicis afferentia, ueluti in alienum fundum ac possessionem irruperant. Cumque non minus inhonestum esset latinis admiscere barbara quam sacris profana, mundis impura ac demum optimis pessima, Arabicis uocibus tamquam iniuste sedem possidentibus in Libycas arenas ablegatis, Latiae et legitimae, quo iuuenibus abunde satisfieret, in noua editione, ut prior illa iactura magno cum fenore resarciretur, suffectae sunt. Atque ex hoc, Hispanolatinum quam plurima mutuatum, cum esset alioqui mutilum et inchoatum, perfectum et omnibus numeris absolutum, summa cum diligentia instauratum est.

Haec cum sint cumulate praestita facile intelligent qui, uel conniuentibus oculis, (absit modo fucus et liuor) librum ipsum semel percurrerint, adductae siquidem sunt innumerae propemodum uoces quae in alia editione desiderabantur, multarum quoque (quae tamen scriptae prius erant) alii significatus quam qui ab Antonio commemorati sunt, ex Latiniis iisque probatissimis scriptoribus $\varepsilon \mu \varphi \alpha \tau \imath \kappa \omega ́ \tau \varepsilon \rho o v$ explicantur. Quarum nonnullae, etiamsi a nostro usu recesserant, eoque nomine minus a rigidis et duris censoribus probari uidebuntur, meminerint uelim eleganter et uere illud scriptum esse:

\footnotetext{
Multa renascentur quae iam cecidere, cadentque

Quae nunc sunt in honore uocabula, si uolet usus,

Quem penes arbitrium est et uis et norma loquendi.
} 
todos os sábios sem exceção lhe reservaram o melhor lugar nas suas bibliotecas. É que, de entre os sábios hispânicos, qual é aquele que, a menos que se trate do mais desagradecido dos homens, não se reconhece muito ajudado pelos desvelos de António e como que despertado de um pesado sono? Quem é que não vê que, depois de editada esta obra de António, em outros países os homens sábios, seguindo com denodo este autor, também escreveram cuidadosamente dicionários de latim-francês e de latim-alemão? E tão-pouco de sua livre e espontânea vontade jamais se teriam abalançado a este trabalho, caso não só não tivessem aprovado assaz o desígnio do nosso autor, mas também não tivessem compreendido que haveriam de repartir abundante fruto por todas as letras e letrados.

Ora, é certo que, há sete anos atrás, ao publicar-se este dicionário sob a tua proteção, lastimei-me de não ter podido expungir algumas falhas, que já estavam impressas e até pareciam ter sido gravadas a ferrete, nem também acrescentar muitas palavras que poderiam aditar-se, porquanto o livro já tinha sido impresso até à letra $O$. Com efeito, desfiguraram esta parte do livro inúmeros vocábulos, pouco respeitadores da pura latinidade, e um sem número de palavras árabes como que violentamente se arrojaram sobre propriedades e terras alheias, oferecendo quiçá alguma fraca utilidade a médicos bárbaros. E uma vez que misturar termos bárbaros com latinos não era menos desonesto e impróprio do que misturar profanidades com cousas sagradas, sujidades com o que é limpo e enfim o ótimo com o péssimo, depois de desterrados para os areais da Líbia os vocábulos arábicos, como quem indevidamente se apropriara do lugar, foram substituídos nesta nova edição, para corrigir com grande vantagem aquele dano da primeira, pelos lídimos e latinos, por forma a satisfazer de sobejo à mocidade. E demais disto, o dicionário espanhol-latim, que se encontrava incompleto e iniciado, foi acrescentado com inúmeras palavras e com o máximo desvelo se oferece completo e totalmente aperfeiçoado.

De quão cabalmente isto se levou a bom termo facilmente se aperceberão os que, mesmo de olhos fechados (contanto que apartados da inveja e mentira), alguma vez os passaram por este livro, visto como se introduziu um quase sem número de palavras de que se sentia a falta na outra edição, e também de muitas que anteriormente constavam expóem-se com maior propriedade $^{38}$ outras significaçóes, extraídas dos mais aprovados escritores latinos, diferentes das registadas por António. Embora muitas destas tenham desaparecido do nosso uso, e por esse motivo hão de semelhar ser menos aprovadas por críticos duros e rigorosos, desejaria que eles se lembrassem de que com elegância e verdade se escreveu o seguinte:

\footnotetext{
Renascerão mil decaídos termos,

E mil decairão, hoje aplaudidos,

Se o uso assim quiser, de cujo arbítrio

O jus e a norma da linguagem pende. ${ }^{39}$
}

38 Em grego no texto original latino.

39 HorácIO, Arte poética, 70-72. Tradução do Visconde de Seabra. 
[Aiij] Ego etenim ita cum doctis semper sensi: "nouorum optima esse quae maxime uetera sunt, et ueterum quae noua", modo Latina lingua locupletior fiat et cum ceteris ausit de ubertate et copia suo iure contendere. Nec sola Latiarum uocum est ingens facta accessio, sed earum quae, passim excusae, in aliis omnibus circumferebantur, diligentissima animaduersio et castigatio. Quibus praeterea dicendi quaedam formulae Hispanis ipsis frequentes et usitatae, suis locis digestae, interseruntur, quo, mutua linguarum facta collatione, propius et elegantius multa pronuncientur quam uulgo dici ac proferri solent. Hoc omnia quantum sint et quam insignem usum studiosis allatura futurum spero legentes multo perspicacius et fructuosius suo commodo discant quam oratione mea consequi possint. Nam, praeter Hispanos, quibus hic liber potissimum esta elaboratus, exteras gentes, siue ipsius linguae peritiam spectent, siue auctorum cognitionem, qui praeclara multa Hispano sermone scripserunt, strenue iuuabit.

Cum igitur, Rector optime, te priori editioni, ob singularem eruditionem, insignem probitatem, amplissimam dignitatem, patronum adoptauerim tuaque existimatione ac nomine multum ponderis et auctoritatis apud lectores habuerit, adeo ut omnia illi fauste, feliciter prospereque euenerint, aequum est si officio tuo minime deesse uelis, ut certe deesse nolles, emendatissimam hanc, multo auctissimam ac utilitatis ubertate omnes, quae ad hanc diem prodiere, superantem, maiore animi alacritate tuearis. Consentaneum siquidem est, postquam etiamnunc Conimbricensem Academiam, nobile disciplinarum emporium, gubernas et moderaris, eorum labores tuo sinu excipias, foueas, probes et amplexeris qui secum quotidie certant, quo se ipsis facti meliores, rei publicae litterariae incrementum afferant. Sic enim tuum officium retinebis perficiesque ut ne minus studia tibi quam tu studiis debeant, et eorum ânimos excitabis qui nihil non sustinent, quo disciplinarum cultum suis sudoribus illustrent, ut remis

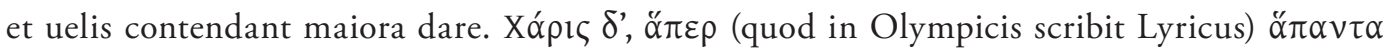

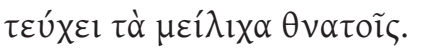

Vale, tui Ludouici non immemor

Parisiis, ex Museo nostro 
[Aiij] É que eu, em consonância com os sábios, sempre pensei que "das palavras novas as melhores são as mais velhas, e das velhas as novas", ${ }^{40}$ contanto que o latim se torne mais opulento e se atreva a com justo título rivalizar com as demais línguas no que tange a riqueza e abundância de léxico. Não houve apenas um acréscimo imenso de vocábulos latinos, mas fez-se uma acuradíssima correção e censura dos que, banidos de toda a parte, se continuavam a publicar em todas as outras edições. Além disso, inseriram-se, repartidos pelos seus lugares, certos modos de falar frequentes e usuais entre os hispânicos, por forma a que, mediante a comparação entre ambas as línguas, se pronunciassem muitas palavras de modo mais elegante e correto do que vulgarmente se costumam dizer e pronunciar. Quão grande e quão extraordinário seja o proveito que tudo isto há de oferecer aos estudiosos tenho a esperança de que os leitores hão de, com proveito seu, aprendê-lo com muito maior evidência e fruto do que posso fazê-lo mediante as minhas palavras. É que, para além dos hispânicos, para os quais sobretudo este livro foi escrito, ajudará sobremaneira os estrangeiros, quer tenham em vista o domínio da língua propriamente dita, quer o conhecimento dos autores que escreveram em espanhol muitas coisas notáveis.

Por conseguinte, ó excelente Reitor, uma vez que, devido ao teu extraordinárioa saber, singular probidade e elevadíssima dignidade, te escolhi como patrono da primeira edição, e sendo certo que graças ao teu prestígio e reputação ela disfrutou de muito peso e autoridade junto dos leitores, a tal ponto que tudo lhe sucedeu a contento e de modo próspero e venturoso, é justo que, se não quiseres faltar à tua obrigação, como certamente não quererás faltar, protejas com o maior entusiasmo esta edição totalmente corrigida, muitíssimo aumentada e que, em riqueza de utilidade, se avantaja a todas as que até hoje se publicaram. Porquanto é razoável que, depois que governas e diriges a Academia de Coimbra, nobre empório das ciências, acolhas no teu seio, favoreças, aproves e abraces os trabalhos dos que todos os dias se esforçam por, tornando-se a si mesmo melhores, acrescentarem a república das letras. De facto, assim cumprirás com a tua obrigação e conseguirás que os estudos não te devam menos a ti do que tu deves aos estudos, e animarás aqueles que a tudo fazem frente, para que com o seu suor enobreçam o culto das ciências, por forma a "com unhas e dentes" se esforçarem por oferecer coisas maiores. O que

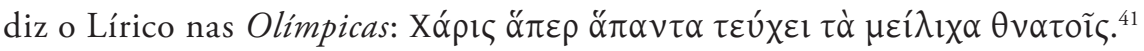

Fica de saúde, e não te esqueças do teu amigo Luís.

Em Paris, do nosso escritório.

40 Cf. QUINTILIANO, Institutio oratoria 1.g6.41: Ergo, ut nouorum optima erunt maxime uetera, ita ueterum maxime noua.

41 Píndaro, $1^{a}$ Ode Olímpica v. 31: "Uma graça que faz de todas as coisas um mel para os homens". 


\title{
Iusti Lipsii epistolarum selectarum centuria tertia ad Belgas,
}

Antuerpiae, ex officina Plantiniana apud Ioannem Moretum, 1602

\section{[3]}

\section{EPISTOLA III}

\author{
Antuerpiam
}

Alvaro Nonio, doctori medico, s. d.

Litteras tuas hodie accepi et in iis duo uidi: magni Etruriae ducis honestum de me iudicium et tuum in me amorem. Neutrum mihi nouum. Nam, et de munere ab eo proposito iamdiu inaudiueram, et tuus affectus olim mihi innotuit, cum ante decem plus minus annos haberet me urbs uestra. Sed quod ad ducem, ita me Deus amet, ut doleo non posse obsequi. Causa est non quaesita ulla aut affectata, sed ipsa ualetudo, sine qua numquam me admouerim iis ad quae desinamur. Iter longum est. Regio olim quidem mihi uisa, sed ad habitanionem nunc noua: et cum ibi ero, quid faciam? Languebo? Vmbram pro Lipsio ostentabo? Medicaea domus, et hic ipse princeps, mihi magnus est et uelim eius causa multa, sed supra uires nihil possum. Ipse Pontifex, caput nostrum, recenter nunc me Romam inuitauit, sed excusamus uerissimo illo ualetudinis pratextu. Sumus quidem in ea curanda, sed melancholici et chronici isti morbi, tu scis quam laneo pede ueniant, et plumbeo, ut sic dicam, recedant. Deus dedit mihi hanc sortem: ferenda est. Scripsi in similem sententiam ante menses tres ad Hieronymum Marcurialem, illustrem medicum et tibi notum, qui primus mihi aperuerat mentem serenissimi ducis. Scio illum accepisse et iam indicium fecisse ubi debebat. Ego te non celo animum mihi in patria esse, etsi afflicta. Deus hanc et me releuabit, cum ei uisum; et te stantem firmumque seruabit, uir clarissime.

Leodici, VIII Kal. Iul 1592 


\title{
[3]
}

\author{
Carta 3 \\ Para Antuérpia \\ Envia saudaçôes a Álvaro Nunes, doutor em Medicina
}

Recebi hoje a tua carta, e nela vi duas cousas: o honroso juízo do grão-duque da Toscana ${ }^{42}$ a meu respeito e o amor que nutres por mim. Nenhuma de ambas é novidade para mim. De facto, não só há muito tempo fora informado do favor com que ele me presenteia, como também no passado me ficou patente o teu afeto quando há cerca de dez anos estive na tua cidade. Mas no que toca ao duque, assim Deus me ame como me punge náo poder comprazê-lo. O motivo não é buscado nem afetado, mas a própria saúde, sem a qual não me teria aplicado ao cargo para que estou designado. A viagem é longa. É certo que se trata de uma região que em tempos visitei, mas nova para hoje lá morar: e quando aí estiver, que farei? Definhar-me-ei na inércia? Oferecerei uma sombra em vez de Lípsio? Tenho em grande apreço a casa dos Médicis e este príncipe em particular, e por amor dele desejaria muitas coisas, mas nada posso acima das minhas forças. O próprio Pontífice, nossa cabeça, recentemente me convidou para Roma, mas escusei-me com o pretexto totalmente verdadeiro do estado da minha saúde. Aplicamo-nos a tratar dela, mas sabes como essas moléstias melancólicas e crónicas vêm com pés de lã e se vão com pés de chumbo, por assim dizer. Deus deu-me este fadário: cumpre-me sofrê-lo. Neste teor escrevi há três meses a Girolamo Mercuriale, ${ }^{43}$ médico ilustre e que conheces: que fora o primeiro a revelar-me os sentimentos do sereníssimo duque. Sei que recebeu a carta e dela deu conta onde devia. Não te oculto que tenho o meu espírito na pátria, ainda que atribulada. Deus há de aliviá-la e a mim, quando Lhe aprouver; e a ti há de conservar-te fero e firme, ilustre varão.

Em Liège, 24 de junho de 1592

42 Era então grão-duque Ferdinando Medici (1549-1609).

43 Célebre médico italiano (1530-1606), conhecido sobretudo pela obra De arte gymnastica libri sex. Sobre ele veja-se o substancial artigo de Nancy G. SIRAISI, "History, Antiquarianism, and Medicine: The case of Girolamo Mercuriale", Journal of the History of Ideas 64.2 (April 2003), pp. 231-251. 
Iusti Lipsii epistolarum selectarum centuria quinta. Miscellanea postuma, Antuerpiae, ex officina Plantiniana apud Ioannem Moretum, 1607

\section{[51]}

EPISTOLA LIII

Antuerpiam

Ludouico Nonio, doctori medico, s. d.

"Diuam" nostram placuisse, tibi pietatis tuae in illam est, fortasse et in me affectus. Nam, a stilo aut ingenio meo [52] leuiter acessit quod commendaret. Gaudeo tamen grata haec esse (nam et ab aliis sic accipio) et excitor ad similes scriptiones. Similes dico, id est, historicas: et tu me eo uocas ualde inclinatum. Itaque iam nunc edo "Monita et exempla politica", in quibus quid nisi florem historiarum excerpo, et huic scriptioni uelut proludo.

Deus si uitam mihi seruat, illuc ibo, firmior sim modo, nam iam a tribus mensibus, mi Noni, ualde uirium et uigoris interni uacuus sum factus.

Te in "Hispania" illustranda pergere gaudeo, et in Marciani Capellae loco (inspexi et inquisiui) a tua correctione nihil muto. Vera et necessaria est: etsi temptabam illud "uniuersa" inuertere, sed non successit. 


\title{
3.
}

\section{[51]}

\author{
Carta 53 \\ Para Antuérpia \\ Envia saudaçôes a Luís Nunes, doutor em Medicina
}

O ter-te agradado a minha $A$ Santa Virgem de Halle $e^{44}$ deve-se à tua devoçáo por ela ou talvez ao teu afeto por mim, pois do meu estilo ou capacidades intelectuais [52] pouco se ajuntou para recomendá-la. Todavia regozijo-me por ter agradado (de facto, também me dou conta de que outros a acolheram do mesmo modo) e sinto-me incitado a composiçóes do mesmo teor, ou seja, históricas: rumo para o qual também impeles quem para ele assaz se inclinava. E assim estou prestes a dar a lume os Monita et exempla politica, ${ }^{45}$ nos quais só extrato a nata das histórias e como que me exercito nesta casta de composições.

Se Deus me conservar a saúde, encaminhar-me-ei para aí, contanto que me sinta mais rijo, pois, meu caro Nunes, de três meses a esta parte que me sinto muito abatido de forças e desvigorado.

Regozijo-me por ver-te prosseguir no abrilhantamento da Hispania, ${ }^{46}$ e na passagem de Marciano Capela (que investiguei e esquadrinhei) não faço qualquer alteração à tua correção. É verdadeira e necessária: embora eu tenha tentado alterar a posição daquele uniuersa ${ }^{47}$ mas debalde.

44 Refere-se ao opúsculo piedoso I. Lipsi Diua Virgo Hallensis, beneficia eius et miracula fide atque ordine descripta. Antuerpiae, ex officina Plantiniana apud loannem Moretum, 1604, 86 pp., mais índices, licenças e privilégios.

45 Monita et exempla politica libri duo, qui uirtutes et uitia principum spectant. Paris, Petrus Chevalier, 1605. De 18 de janeiro deste ano está datada a dedicatória do Autor ao arquiduque Alberto de Áustria.

46 Refere-se à Ludouici Nonii HISPANIA siue Populorum, Vrbium, Insularum ac Fluminum in ea accuratior descriptio, cuja primeira edição saiu no ano de 1607, em Antuérpia, ex officina Hieronymi Verdussi, e que no ano seguinte o jesuíta André Schott incluiu no volume IV da Hispania Illustrata, publicado em Francoforte, apud Claudium Marnium et heredes loan. Aubrii: edição que seguimos para as transcrições, conquanto tenhamos feito o cotejo com o texto da $1^{\mathrm{a}}$. 0 prefácio-dedicatória de Nunes à sua Hispania, escrito em Antuérpia, tem a data do $1^{\circ}$ de março de 1607.

47 Vejam-se os termos em que Nunes formula a sua correção textual, aqui aprovada por Lípsio: Non praetereundum puto apud Martianum Capellam, ubi de Hispania agit, lib. VI, lacunam esse supplendam. Ita enim ait: 'At uniuersa prouincia habet conuentus septem, Carthaginensem, Tarraconensem etc'. Quae 
Quaeris super Strabonis loco de "Balearium laticlauia tunica", et meretur quaeri. Ego autem simpliciter ita accipio, usos primum $\pi \lambda \alpha \tau v \sigma \eta ́ \mu o เ \varsigma \chi \tau \tilde{\omega} \sigma \mathrm{l}$, quas Romani senatores usurparunt, sed paulo aliter. Nam Baleares, opinor, in lino, non in lana, et ab iis haud dubio Hispani sumpserunt, sic propinqui. Sane de istis in Liuio est, lib. XxI, ubi de pugna Cannensi: "Hispani

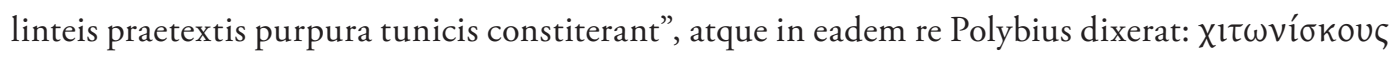

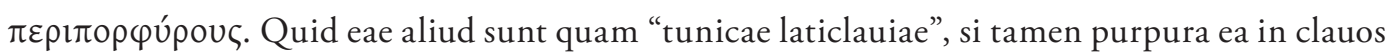
distincta? Haec ad Liuium olim notabam et Strabonis locum adiungebam: tu iudicabis.

enim uniuersa prouincia habet septem conuentus? An Hispania? Sed superius dixerat Baeticam duos habere conuentus, atque ita erunt nouem. Quare ita legendum puto: 'At uniuersa citerior prouincia conuentus habet septem.' Nam de Baetica et Lusitania egerat, restabat de Tarraconensi dicere.

["Penso que não deve deixar passar-se sem correção uma falta na obra de Marciano Capela, quando se ocupa da Hispânia, no livro $6^{\circ}$. É que diz o seguinte: 'Mas a província toda tem sete conventos: o Cartaginense, o Tarraconense' etc. Ora, que província tem sete conventos? Acaso a Hispânia? Mas mais atrás dissera que a Bética tem dois conventos, e desse modo serão nove. Motivo pelo qual considero que deve ler-se do modo seguinte: 'Mas a província citerior toda tem sete conventos.' Com efeito, ocupara-se da Bética e da Lusitânia, e faltava tratar da Tarraconense."] Hispania Illustrata, IV, p. 422 (c. 40). 
Perguntas-me sobre a passagem de Estrabão relativa à túnica com banda larga ${ }^{48}$ dos habitantes das Baleares, e é interessante a pergunta. Ora, eu simplesmente interpreto no sentido de que foram os primeiros a usarem as túnicas de banda larga ${ }^{49}$ que usaram os senadores romanos, mas com uma pequena diferença. É que, em minha opinião, as dos baleares eram feitas de linho, e não de lâ, e foi sem dúvida deles que os hispânicos, dada a grande proximidade, tomaram as suas. Destes fala Lívio no livro $21,{ }^{50}$ onde escreve, a propósito da batalha de Canas: Os hispânicos tinham-se disposto em linha com túnicas de linho bordadas a púrpura, e, escrevendo sobre o mesmo assunto, dissera Políbio: com túnicas curtas bordadas a púrpura. ${ }^{51}$ Por que são estas uma coisa diferente das túnicas de banda larga ou laticlavos, se também se distinguem pela púrpura nas bandas? Já no passado este detalhe despertava a minha atenção em Lívio e confrontava-o com o passo de Estrabão: tu ajuizarás. ${ }^{52}$

48 Ou laticlavos.

49 Em grego no original.

50 Este passo de Tito Lívio hoje identifica-se como pertencente ao c. 46 do livro 22.

51 Em grego no original. 0 passo de Políbio pertence ao c. 114 do livro $3^{\circ}$ das Histórias.

52 E de facto, no seu epítome histórico-geográfico, publicado menos de três anos depois desta carta, o Dr. Luís Nunes exerceu de alguma forma o seu juízo crítico sobre o material informativo que o compatriota aqui the ofereceu, e ele então transcreve e agradece, pois, ocupando-se, no c. 95, das ilhas Baleares, escreve o seguinte:

Memorat et Strabo, lib. III, primos omnium mortalium Baleares laticlauium induisse [...] mirorque apud rudes et incultos homines senatoriae dignitatis ornamentum primo repertum fuisse. Num uero hinc ad Romanos tunica laticlauia peruenerit, nulla mihi ratio suadet ut credam: praesertim cum Plinius, lib. IX, cap. $X X X I X$, refert latiore clauo Tullum Hostilium primum e regibus, deuictis Etruscis, usum fuisse, multis annis priusquam Baleares P. R. noti essent. Clarus lustus Lipsius, unicum rei litterariae (heu quondam) decus, suis ad me litteris credit Baleares $\pi \lambda \alpha \tau v \sigma \eta ́ p o r \varsigma ~ x \imath \tau \tilde{\omega} \sigma \mathrm{r}$ usos primum; quas Romani paulo aliter usurparunt, in lino nempe illi, non in lana: a quibus et Hispani ita uicini sumpserunt. De quibus Liuius, lib. xxı: 'Hispani

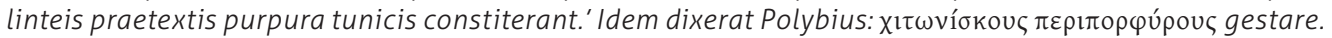
Non erat forsan purpura ea in clauos distincta, nec tam augusta ut senatorum laticlauus.

["Também regista Estrabão, no livro 30, que os primeiros homens a usarem laticlavos foram os habitantes das Baleares [...] e espanto-me de que entre homens boçais e rudes se encontrasse pela primeira vez o ornamento próprio da dignidade senatorial. De facto, nenhum motivo me convence de que tenha tido esta origem a túnica de bandas largas dos romanos: sobretudo sendo certo que Plínio, no livro $6^{\circ}$, c. 39, conta que Tulo Hostílio foi o primeiro de entre os reis a, depois de vencidos os etruscos, usar a túnica de bandas largas, muitos anos antes de os romanos terem conhecimento do povo das Baleares. O ilustre Justo Lípsio, lustre e glória sem igual das letras (infelizmente, em dias que já lá vão!), em carta que me escreveu, afirma crer que os baleares foram os primeiros a usarem as túnicas de banda larga que usaram os senadores romanos, mas com uma pequena diferença: a saber, que aquelas eram feitas de linho, não de lã, sendo deles que os hispanos, dada a grande proximidade, as tomaram. Destes fala Lívio no livro 21: Os hispânicos tinham-se disposto em linha com túnicas de linho bordadas a púrpura. E o mesmo dissera Políbio: que levavam túnicas curtas bordadas a púrpura. Provavelmente esta púrpura não se destacava tanto nas bandas nem era tão majestosa como o laticlavo dos senadores."] Hispania Illustrata, IV, p. 471. 
Publica ualde me suspensum habent et uideo certamen omne in Flandria cernendum. Hostis copias auxisse, instruxisse dicitur, et recta ad nouam expeditionem ire. Nos quid? Quod tu scitissime a tua arte: in ueterno aut lethargo sumus, Nec ecxitati excitamur. Ades, o Deus, et patriam, aut certe religionem tuam, uindica et tuere!

\section{Vale, mi Noni}

Louanii, XI Kal. Octobris 1604 
Os negócios públicos deixam-me sobremaneira ansioso e vejo que toda a sorte de pelejas devem combater-se na Flandres. Corre a voz de que o inimigo aumentou as tropas e pôs-se em campo e se abalança diretamente para nova campanha. E nós que fazemos? Tal como mui a fundo conheces da tua arte, permanecemos em estado de modorra e letargia, e nem espicaçados reagimos. Acode-nos, ó Deus, e protege e defende a pátria: ou antes, a Tua religião!

Fica bem, meu caro Nunes

Em Lovaina, 21 de setembro de 1604 
4.

Roderici a Castro Lusitani (...) De uniuersa mulierum medicina (...), Coloniae, 1603.

\title{
[3]
}

\author{
D. Roderici a Castro, Lusitano, Ludouicus Nonius, \\ doctor medicus, Lusitanus
}

Ciuica si ciui seruato a morte corona

Sit data, et e lauro uirgine cincta coma

Si quibus hostili rorabant membra cruore

Contigit et multa caede triumphum erat:

Innumerae umbrabunt merito tua tempora lauri,

A Castro, et lambet multa corona caput,

Innumeros homines solus nam subtrahis Orco

Et facis inuita uiuere posse colo.

Ipse fugas imo latitantes corpore pestes,

Agmina morborum disiicis arte tua,

Disiicis arte tua Pandorae quidquid in orbem

Saeua tulit pyxis, quidquid et ira deum.

Mortaleis artus crebra ne tabe fatiscant

Efficis et diro soluis ab interitu.

Nec, Roderice, satis quod per te annosa Charontis

Cymba fuit totiens ludificata senis,

$\mathrm{Ni}$ postquam Lachesis rumpes subtegmina uitae

Sentiat ex calamo pluria damna tua. 


\section{4.}

\section{[3]}

\section{Ao Senhor Rodrigo de Castro, português, o doutor Luís Nunes, médico português}

Se a coroa cívica se concedia por da morte salvar

Um cidadão, e cingir as comas com puro louro

Em sorte coube aos que rociavam os membros com sangue imigo

E jus tinham ao triunfo por prémio de vasta matança:

Será justo que lauréis sem conto sombreiem tua fronte,

E que coroas muitas, ó Castro, te cinjam a cabeça,

Pois são sem conto os que tu só arrebatas à morte

E fazes que viver possam, em que pese à Parca.

Afugentas as pestes que no fundo do peito se rebuçam,

Com tu'arte desbaratas os esquadrôes de doenças,

Desbaratas com tu'arte tudo que sobre o mundo

Deixou cair a cruel caixa de Pandora e soltou a ira dos deuses.

Consegues que a galopante putrefação não desfaça

Os membros mortais e os livras da terrível morte.

Nem basta, ó Rodrigo, o teres tão amiúde logrado

A anosa barca do ancião Caronte,

Se Láquesis, depois de cortar o fio da vida,

Não sentir danos infindos por obra de tua pena. 
Iusti Lipsii sapientiae et litterarum antistitis fama postuma, Antuerpiae, ex officina Plantiniana apud Ioannem Moretum, 1607

\section{[52]}

In v. c. Iustum Lipsium epicedion

Ludouici Noni, doctoris Medici

Magna anima, aetherium quam supra euexit Olympum

Aeternus genitor solioque locauit auito:

Da faciles threnis aures, ne subtrahe uultum,

Nenia funereos mea dum persoluit honores

Et bustis extrema tuis epicedia cantat.

At quinam gemitus uel quae lamenta dolori

Sufficient? Claros cineres, quae praefica, Lipsi,

Perfundet lacrimis? An quae maestissima mater

In Sipylo queritur bis senas Tantalis urnas?

An fletu liquefacta suo Maeandria Byblis?

An Phaethonteo quae in funere diriguerunt

Heliades? Anne Eois emersus ab undis,

Ferales planctus Hyadum chorus occinet orbi?

Tu longaeua Themis, docta tu Pallas ab arce,

Dic tumulo lessos, et singultantia luctu

Plectra moue, et taxis crines et tempora uela:

Ante fores nullo frondescat culmine laurus,

Sed plorata tuos postes cyparissus obumbret.

Nam cecidit uates, Helicon, tuus! O ubi tristes

Siccabis lacrimas Grudium? Quanto undique questu 


\title{
5.
}

\section{[52]}

\author{
Epicédio à memória do varão Justo Lípsio, \\ por Luís Nunes, doutor em Medicina
}

Grande alma, que o eterno Criador elevou acima do étereo Olimpo

E colocou no trono de seus maiores:

Escuta de bom grado e não te esquives aos prantos,

Enquanto a minha nénia presta as honras fúnebres

E entoa às tuas cinzas o canto do adeus derradeiro.

Mas que gemidos ou que lástimas hão de bastar à dor?

Que carpideira, ó Lípsio, cobrirá de lágrimas os ilustres teus despojos?

Porventura a tristíssima mãe, filha de Tântalo,

Que no Sípilo pranteia as doze urnas?33

Porventura a meândrica Bíblis, liquefeita com o seu próprio choro? ${ }^{54}$

Acaso as Helíades ${ }^{55}$ que congelaram nos funerais de Faetonte?

Porventura soltará plangitivos trenos o coro das Híades, ${ }^{56}$

Assomando das levantinas ondas?

Tu, longeva Témis, tu, Palas, desde o alto da sábia Acrópole

Dize palavras de lástima ao túmulo,

E que o luto te arranque da lira suspirosos acordes,

E com teixos cobre melenas e têmporas:

Que diante da porta não frondeje o louro em nenhum viso,

Mas o choroso cipreste sombreie a tua soleira.

É que, ó Hélicon, tombou o teu vate!

Oh quando estancarás as tristes lágrimas dos Grúdios?57

53 Alusão a Níobe, pranteando os filhos mortos.

54 Como pode ver-se em OvíDıo, Metamorfoses 9, 446-665, Bíblis, filha de Meandro, loucamente apaixonada pelo irmão Cauno, acabou literalmente desfeita em pranto.

55 Filhas de Hélio e, por conseguinte, irmãs de Faetonte.

56 Ninfas, filhas de Atlas, que Zeus metamorfoseou na constelação que perpetua o seu nome.

57 Povo da Gália Belga a que Júlio César se refere em 5. 39, e que habitou na região de Justo Lípsio. 
Pulpita, Cecropiis certantia pulpita Athenis,

Maesta sonant? Vacuae lugent doctore cathedrae.

[53]Martia sic magni in Ciceronis funere Roma

Ingemuit quondam Latiaeque silentia linguae,

Vos septem colles, uos flestis rostra Quirini.

Sanctius ecquis enim coluit sacraria Phoebi?

Gorgoneo admouit quis dignius ora liquori?

Testis inexhausto est facundia pectore diues,

Seu libuit uincire modis effamina certis,

Seu libuit uoces animare lepore soluto.

Qualiter assurgis! Quam denso pondere mentes

Afficis et dulci perfundis nectare sensus!

Non tibi Nelides, non se tibi conferet heros

Dulichius, breuitate potens non frater Atridae.

Non tua Tellenis turgescit pagina nugis

Aut populo phaleras et inania cymbal uendit,

Sed solidae passim uirtutis semina spargit

Lectoremque auidum generoso replet honesto.

Nec tibi morosa dictatur epistola cura,

Ast facilis nulloque uenit impulsa labore.

Non ieiuna tamen, ridenda aut ilia ducit,

Cecropio sed melle madet Latioque lepore.

Tu miseros Belgas, afflatus turbine belli,

Erigis eloquio magnisque hortatibus imples.

Et tua nos docuit Constantia ferre pericla

Atque animum infirmum triplici firmare metallo 
Com quão grandes queixumes por toda a parte ressoam

Os contristados estrados, os estrados que emulavam a Cecrópia Atenas?

Desocupadas do mestre, as cátedras lacrimejam.

[53] Assim antanho no funeral de Cícero a marcial Roma

Gemeu de dor, e pranteastes o silenciar da língua latina,

Vós, ó sete colinas, e tu, ó tribuna de Quirino.

De feito, mais santamente cultuou alguém o santuário de Febo?

Quem mais dignamente libou a gorgónea leiva?

E disso é prova a fácil facúndia no peito nunca lasso,

Quer lhe tenha aprazido ligar as frases com ordem e medida,

Quer aviventar tenha querido as palavras com lépida graça.

Como avultas! Com quão densa carga provês os entendimentos

E com quão doce néctar impregnas os sentidos?

Nem o filho de Neleu ${ }^{58}$ nem o herói Dulíquio, ${ }^{59}$ senhor da concisão,

Nem do Atrida o irmão, ${ }^{60}$ contigo sofrem cotejo.

Os teus escritos náo se incham com nonadas frívolas

Ou arrebiques para engodar o povo; ${ }^{61}$ táo-pouco vendem ocos adufes,

Mas por toda a parte esparzem sementes de sólida moral

E ao leitor ávido colmam de generosa virtude.

Não redigias as cartas com detençoso cuidado,

Mas fáceis te fluiam e sem te exigir esforço algum.

Todavia, o seu conteúdo não é magro ou de somenos,

Mas ressuma mel ático e latina graça. ${ }^{62}$

Com tua eloquência, alentas os mofinos Belgas,

Batidos pelo turbilhão da guerra, e os esforças com exortaçóes de peso.

A tua Constância ${ }^{63}$ nos ensinou os perigos a suportar

E a fortificar com tríplice metal o esmorecido ânimo

\section{Nestor.}

59 Ulisses.

60 Menelau.

61 Cf. PÉRSIO, 3.30.

62 O nutrido epistolário seleto de Lípsio foi reunido em diversos volumes, intitulados Centúrias, dos quais o último de publicação póstuma (1607).

63 Alusão à obra talvez mais divulgada de Justo Lípsıo: De constantia libri duo, qui alloquium praecipue continent in publicis malis. Leiden, Plantino, 1584. 
Fortunae aduersus ludos et lubrica rerum.

Tu ueterum mores scabra robigine saecli

Eripis atque nouo cogis splendescere cultu.

Per te nigrantes Mauortia Roma fauillas

[54]Excutit et longae posito squallore senectae,

Ecce alios iterum melior iuuenescit in annos.

Iam priscas miratur opes et robora regni

Et modo Tarpeio Capitolia celsa Tonantis

Fulgere colle stupet, circum delubra deorum

Obtundunt trepidos oculos fulgore metalli.

Innumeri hinc arcus spoliisque ornata tropaea;

Hinc Thermae occurrunt; hinc admiranda theatra;

Deliciasque suas, saeuae spectacula arenae

Atque theatrales gaudet cognoscere plausus.

Consiliis monitisque tuis, uestigia regum

Lubrica componis, Consi penetralibus haustis,

Queis populos iustis ualeant compescere habenis.

Iam te quis Martis tenuit felicius artes?

Militiae dum prisca doces praecepta Quiritum;

Queis tectus ueniat telis in proelia miles;

Qua deceat fossa ualloue includere castra;

Moenia quam uario prosternat machina pulsu: 
Contra os caprichos do destino e as ciladas da vida.

Os costumes dos antigos tu os arrancas

$\mathrm{Da}$ áspera ferrugem do tempo

E a resplanderecem os obrigas com primor renovado.

Graças a ti, a mavórcia Roma as enegrecidas cinzas

[54] Sacode e, perdendo a sujidade da longa velhice,

Ei-la que melhorada se remoça para viver de novo.

Já olha com espanto para as antigas riquezas

E para o poderio do império, e em seguida vê com pasmo

No Tarpeio monte os tetos reluzirem do Capitólio do Tonante.

Em torno, com seu fúlgido metal os templos das divindades

Encandeiam os pasmados olhos.

De um lado, à vista se lhe presentam triunfais arcos sem conta

Ornados com despojos; do outro, as Termas;

Acolá, os admiráveis teatros; e se alegra

Ao reconhecer a menina dos seus olhos,

Os espetáculos da cruel arena e os aplausos teatrais. ${ }^{64}$

Depois de penetrares os recessos das decisóes secretas,

Corriges as incertas pisadas dos reis

Com teus conselhos e advertências, para que com estes possam

Os povos dirigir com rédeas justas. ${ }^{65}$

Quem, com mais felicidade do que tu,

As artes dominou de Marte?

Quando ensinas os antigos preceitos da milícia dos Quirites,

As armas com que o soldado se protege ao lançar-se à peleja;

Com que fossos ou valas convém rodear o arraial; ${ }^{66}$

Com quanta diversidade de tiros

Os bélicos engenhos derrubam as muralhas: ${ }^{67}$

64 Referência verosímil ao livro lipsiano Admiranda siue de magnitudine Romana libri quatuor. Paris, apud Ambrosium Drouard, 1598.

65 Talvez Nunes pretenda fazer aqui menção da mais importante obra de doutrinação política do polígrafo flamengo: Politicorum siue ciuilis doctrinae libri sex. Leiden, Plantino, 1589.

66 Tem aqui Nunes provavelmente em mente a obra Iusti Lipsii de militia Romana libri quinque, commentarius ad Polybium. Antuerpiae, ex officina Plantiniana apud uiduam et loannem Moretum, 1595.

67 Visa o nosso Autor com toda a probabilidade o livro lusti Lipsii Poliorceticon siue de machinis, tormentis, telis libri quinque. Antuerpiae, ex officina Plantiniana apud uiduam et loannem Moretus, 1596. 
Martis quae tantum pubes miratur, ut ultro

"Cedant arma togae, concedat laurea linguae."

Singula quid memorem? Non uestigata priorum

Ingeniis tenebrisque diu damnata profundis

Extrahis et primus luci committis apertae.

Te sine Zenonis latuissent scrinia. Magnum

Crantora quis nosset demorsoque ungue Cleanthem

$\mathrm{Ni}$ tu Stoicidum renouasses atria sectae?

Quid loca senta situ scriptorum aut mersa ueterno,

Vindice te, referam, solitum spirare decorem?

[55]Non Toto in Augeae stabulo exanclasse labores,

Eurysthi imperio, fertur Tyrinthius heros

Taedia quot passus, dum caeca nocte latentes

Eripis auctores, mendis blattisque fugatis.

Luce noua melior Tacitus Senecaeque coruscant,

Atque alii proceres, Latium quos uidit et Hellas,

Pileolo ornati, raso te uertice, Lipsi,

Sectantur cuncti: sic, libertate recepta,

Hostile fuerant quondam qui carcere clause,

Laeta triumphalis comitantur syrmata pompae.

Quam tibi blanditur Iessei germinis altrix?

Illa, cui extremos calamus seruauit honores, 
Então, com tanto espanto a márcia gente

Os olhos põe em teu saber, que livremente:

"As armas cedem à toga e à língua concede os louros." 68

Para quê em cada um tocar de teus títulos de glória?

Trazes à luz o que os passados não rastearam,

E o que por longo tempo ficou condenado a cerradas trevas

És o primeiro a restitui-lo à plena luz.

Não foras tu, e os tesoiros de Zenão teriam permanecido ocultos.

Quem teria tido conhecimento do grande Crantor ou de Cleante

$\mathrm{Se}$, depois de fadigas muitas, ${ }^{69}$ não tivesses restaurado

$\mathrm{O}$ átrio da seita dos Estóicos? ${ }^{70}$

Para quê referir como, salvas por ti, mostram seu nativo luzimento

Os passos, afeiados pelo desleixo dos copistas

Ou tragados pela longa idade?

[55]Diz-se que o herói Tiríntio, ${ }^{71}$ por ordem de Euristeu,

Nas cavalariças de Augias tanto trabalho não tivera

Quanto a fadiga que suportaste quando,

Rechaçando as faltas e as traças,

Os autores restauraste que se escondem na cega noite.

Tácito e os Sénecas ${ }^{72}$ melhorados brilham com nova luz,

E outros, de entre os grandes que o Lácio e a Hélade viram,

Ornados com pequenos píleos, a ti,

Que vais de cabeça raspada, ó Lípsio,

Te seguem num corpo só: tal como, após receberem a liberdade,

Os que outrora tinham estado encerrados em cárcere hostil,

Acompanham as alegres vestes roçagantes do cortejo triunfal.

Quanto te atrai a aleitadora do rebento de Jessé?73

Ela, para quem a pena reservou as derradeiras honras.

68 Cícero, De officiis 1. 22.

69 O Autor utiliza aqui uma expressão presente na sátira $1^{\text {a }}$ de Pérsio.

70 Alusão às obras lusti Lipsii Manductionis ad Stoicam philosophiam libri tres: L. Annaeo Senecae aliisque scriptoribus illustrandis. Antuerpiae, ex officina Plantiniana apud loannem Moretum, 1604, e Physiologiae Stoicorum libri tres: L. Annaeo Senecae aliisque scriptoribus illustrandis. Antuerpiae, ex officina Plantiniana apud loannem Moretum, 1604.

71 Hércules.

72 Como se sabe, a Justo Lípsio ficaram a dever os estudos clássicos edições criticamente depuradas e comentadas de inúmeros autores latinos, para além dos aqui expressamente nomeados pelo Dr. Nunes.

73 Is 11. 1-3. 
Dum quae Belga uidet, per te miracula uulgat,

Quaeque prius Hallis, nunc patrat Colle Sichemi:

Talia quae ueniens auida bibet aure uetustas

Iuratasque dabit fidei euanescere pestes.

Sed quid ego haec? Inopi sperem deducere uena,

Ingenii monumenta tui! Quae dicere fama

Nulla potest, quamuis centeno personet ore.

I, Musa, et cordis te per penetralia gyrans,

Arcanos animi penitus expende recessus.

An referes faciles et non sine pondere mores?

An niueum et nulla tinctum ferrigine pectus?

Quae probitas oris? Frontisque modestia quanta?

Illa dedit saeuas te sustentare procellas

Inuidiae et rabidae contemnere proelia linguae.

$\mathrm{Nec}$ tua in alterius iugulum facundia famae

Hac duce descendit dentesque armauit acutos,

[56] Sed cum alii plenis spargunt conuicia plaustris,

Innocuos tantum lusus sine felle reponis.

At quid in immenso laudum aequore naufragus erro?

Nam decus hoc, dignum meliori uiuere saeclo

(Ah dolor! Ah lacrimae!), mors inuida sustulit orbi,

Redderet ut caelo, caelestis particulam aurae

Vtque nouum patrio sociaret sidus Olympo.

Felix o nimium Lipsi, qui saxa dolosa

Et dubios uitae scopulos Syrtesque latentes

Emensus, tandem tuta in statione locaris. 
Enquanto o Belga os vê, divulga através de ti seus milagres,

Quer os que primeiro obrou em Hallen, ${ }^{74}$

Quer os que obra agora na colina de Zichem: ${ }^{75}$

Tais que com ávidos ouvidos há de vir a escutá-los a posteridade

E acreditará que se desvaneceram as pestes rogadas em praga.

Mas para quê estou a dizer estas coisas? Como se,

Com inspiração apoucada, esperasse apresentar

Os monumentos da tua inteligência! Que nenhuma fama

Pode jamais dizer, ainda que retumbe por um cento de bocas.

Vai, ó Musa, e girando pelos recessos do coração,

Examina a fundo os secretos penetrais da alma.

Darás acaso conta de um caráter acessível e ponderado?

Acaso de um peito cândido e sem mácula de inveja?

Quanta probidade transluz o semblante!

Quão grande comedimento que se revê na face!

Graças a este arrostaste com as cruéis tempestades do ódio

E desprezaste os ataques das línguas raivosas.

Nem, com este guia, a tua eloquência se rebaixou

A abocanhar a fama de outrem

Ou contra o próximo armou afiados dentes,

Mas, quando os outros espalham baldóes às carradas,

Retrucas apenas com inocentes gracejos sem fel.

[56]Mas por quê erro náufrago num imenso pego de louvores?

É que a esta glória, digna de viver em melhor século,

(Ah dor! Ah lágrimas), arrebatou-a ao mundo a invejosa morte,

Para restituir ao céu esta porção da luz celestial

E para associar um novo astro ao pátrio Olimpo.

Ó Lípsio deveras bem-aventurado,

Que, depois de atravessar os tredos arrecifes

E os escolhos incertos da vida e as ocultas sirtes,

Finalmente te encontras colocado em morada segura:

74 Alusão ao opúsculo piedoso atrás citado, no qual Lípsio historiava, coligia e exaltava os milagres da Virgem Negra cuja imagem se cultua naquela cidade flamenga.

75 Referência ao opúsculo piedoso I. Lipsii Diua Sichemiensis siue Aspricolis, noua eius beneficia et admiranda. Antuerpiae ex officina Plantiniana apud loannem Moretum, 1605, 75 pp. Nesta obrinha, como indica o título, relatam-se as mais recentes graças e milagres atribuídos à Virgem cultuada no santuário mariano da cidade flamenga de Zichem. 
Iam tenebris expers et uera luce refulges,

Illustres inter cuneos Manesque beatos,

Hic ubi perpetuo uia lactea lumine candet,

Vnde hominum miserans despectas uiuere inane

Et patriae ancipites casus et tristia fata.

Respice nos felix supremaque munera busti,

Quae tibi funesto soluit mens saucia luctu,

Suscipe, et affectus ne despice, Iuste, benignos.

Sic leuior semper tellus tibi uernet in urna,

Ossaque sic tumulo molli composta quiescant. 
Já livre estás das trevas e resplandeces com a verdadeira luz,

No meio dos luzentes esquadrôes e das almas bem-aventuradas:

Aí onde com luz perpétua alveja a via láctea,

Aí, donde olhas de alto e compassivo o vão viver dos homens

E os incertos sucessos e triste fado da pátria.

Venturoso, póe em nós os olhos e recebe as derradeiras homenagens

Que diante da tumba te presta um espírito abatido por funéreo luto,

E a desprezo não votes, ó Justo, um sentimento de lídimo afeto.

Que assim sobre a urna mais leve sempre te reverdeça a terra

E que assim descansem teus ossos, tranquilos em doce tumba. 


\section{BIBLIOGRAFIA}

Amato Lusitano, In Dioscoridis Anazarbei de medica materia libros quinque enarrationes eruditissimae. Venetiis, apud Gualterum Scotum, 1553.

Andrade, António Manuel Lopes, "Ciência, Negócio e Religião: Amato Lusitano em Antuérpia": in Inês de Ornellas e Castro, Vanda Anastácio (coord.), Revisitar os Saberes - Referências Clássicas na Cultura Portuguesa do Renascimento à Época Moderna. Lisboa, Centro de Estudos Clássicos - Faculdade de Letras da Universidade de Lisboa, 2010, pp. 9-49.

Andreas, Valerius, Bibliotheca Belgica. Lovanii, apud Henricum Hastenium, 1623; ibidem, typis Iacobi Zegers, 1643.

Arceo, Francisco, De recta curandorum uulnerum ratione et alii eius artis praeceptis libri II. Antuerpiae, Christophorus Plantinus, 1574.

Beyerlinck, Laurentius, Opus Chronographicum orbis uniuersi ab anno 1572 usque ad annum 1611. Antuerpiae, ex typographeio Hieronymi Verdussii, 1611.

Brandão, Mário, Actas dos Conselhos da Universidade de 1537 a 1557, volume I. Coimbra, Imprensa da Universidade, 1941.

Bruce-Chwatt, Leonard Jan, "Ludovicus Nonnius, M. D., 1553-1645”, Bulletin of the New York Academy of Medicine, 60.9 (November 1984), pp. 938-943.

Castro, Rodrigo de, Roderici a Castro Lusitani (...) De uniuersa mulierum medicina (...). Coloniae, 1603.

Enzinas, Francisco de, Epistolario de Francisco de Enzinas. Texto latino, traducción española y notas de Ignacio J. García Pinilla. Genebra, Librairie Droz, 1995.

Ferraz, Amélia Ricon, “The Portuguese background of Ludovicus Nonnius”, Derde Symposium Geschiedenis der geneeskundige wetenschappen. Nonius en de 'dietetiek'. 2 december 1995. Academia Regia Belgica medicinae - Dissertationes - Series Historica, 5. Bruxelas, Kon. Akademie voor Geneeskunde, 1996, pp. 55-66.

Ferreira, Francisco Leitão, Notícias Cronológicas da Universidade de Coimbra, edição publicada, revista e anotada por Joaquim de Carvalho, 2a parte, volume II. Coimbra, Imprensa da Universidade, 1940.

Frade, Florbela Veiga, As relaçôes económicas e sociais das comunidades sefarditas portuguesas. O trato e a família: 1532-1632, tese de doutoramento em História Moderna apresentada à Faculdade de Letras da Universidade de Lisboa, 2006 (policopiada).

Laguna, Andrés, Pedacio Dioscorides Anazarbeo, Acerca de la materia medicinal y de los venenos mortiferos, traduzido de lengua griega, en la vulgar castellana. Anvers, Iuan Latio, 1555.

Lemos, Maximiano, "Amato Lusitano. Correcçôes e aditamentos. Amato Lusitano nos Países Baixos", Revista da Universidade de Coimbra 10 (1927), pp. 5-38.

Lípsio, Justo, Iusti Lipsii epistolarum selectarum centuria quinta. Miscellanea postuma. Antuerpiae, ex officina Plantiniana apud Ioannem Moretum, 1607.

Lípsio, Justo, Iusti Lipsii epistolarum selectarum centuria quinta. Miscellanea postuma. Antuerpiae, ex officina Plantiniana apud Ioannem Moretum, 1607. 
Lípsio, Justo, Iusti Lipsii epistolarum selectarum centuria tertia ad Belgas. Antuerpiae, ex officina Plantiniana apud Ioannem Moretum, 1602

Lípsio, Justo, Iusti Lipsii sapientiae et litterarum antistitis fama postuma. Antuerpiae, ex officina Plantiniana apud Ioannem Moretum, 1607.

Machado, Diogo Barbosa, Bibliotheca Lusitana, histórica, critica e cronológica na qual se comprehende a noticia dos authores portugueses e das obras, que compuserão desde o tempo da promulgação da ley da Graça até o tempo prezente. Lisboa, na officina de António Isidoro da Fonseca, 1741-1759, 4 vols.

Nebrija, Élio António de, Dictionarium latinumbispanicum. Antuerpiae, Iuan Steelsius, 1545 e 1553.

Nunes, Luís, Diaeteticon. Antuerpiae, apud Petrum Bellerum, 1645.

Nunes, Luís, Ludouici Nonii HISPANIA siue Populorum, Vrbium, Insularum ac Fluminum in ea accuratior descriptio, cuja primeira edição saiu no ano de 1607, em Antuerpie, ex officina Hieronymi Verdussi, 1607 (2a edição apud Hispania Illustrata, edição de André Schott, volume IV. Francoforte, apud Claudium Marnium et heredes Ioan. Aubrii, 1608).

PoHL, Hans, Die Portugiesen in Antwerpen, 1567-1648: zur geschichte einer Minderheit. Wiesbaden, Franz Steiner, 1977.

Ramalho, Américo da Costa, "O 'Doctor Ludovicus Nonius' retratado por Rubens", Mundo da Arte 16 (Dezembro de 1983), pp. 15-18.

Ramalho, Américo da Costa, Latim Renascentista em Portugal. Coimbra, Centro de Estudos Clássicos e Humanísticos, 1985.

Romano, Marco, "Rubens e l'erma ritratto di Ippocrate. La memoria dell'antico in un ritratto di Ludovicus Nonnius", Journal of History of Collections 22.1 (2010), pp. 15-27.

Siraisi, Nancy G., "History, Antiquarianism, and Medicine: The case of Girolamo Mercuriale", Journal of the History of Ideas 64, n. 2 (April 2003), pp. 231-251.

Sweertius, Franciscus, Athenae Belgicae siue Nomenclator inferioris Germaniae scriptorium. Antuerpiae, apud Guglielmum a Tungris, 1628.

TRICOT, Jean-Pierre, Ludovicus Nonnius (1553-1645): humanistisch geneesheer, grondleger van de medische dietetiek. Beveren, Herman Cols, 1984.

Viterbo, Sousa, Notícia sobre alguns médicos portugueses ou que exerceram a sua profissão em Portugal. Segunda série. Lisboa, 1895. 
A partir dos alvores do século XVI, a matéria médica torna-se indiscutivelmente um tema de primeira grandeza entre os membros da República das Letras, objecto de estudo e de controvérsia entre os mais notáveis humanistas europeus, em particular entre os cultores da arte médica. Entre os autores em destaque neste volume encontram-se, à cabeça, os nomes de Amato Lusitano, Garcia de Orta e Nicolás Monardes, famosos pelos contributos valiosos que deram para o conhecimento do mundo natural. 0 volume encontra-se dividido em duas partes: a primeira, subordinada ao título "Humanismo e Ciência", alberga os estudos que versam sobre todos os autores estudados, à excepção de Amato Lusitano; a segunda está reservada a um conjunto de trabalhos dedicados exclusivamente ao médico albicastrense, cuja autoria se fica a dever, em boa parte, aos membros da equipa do projecto de I\&D "Dioscórides e o Humanismo Português: os Comentários de Amato Lusitano", tomando, por isso, 0 seu próprio título. Nesta segunda parte, oferece-se, desde já, aos leitores uma amostra significativa do trabalho desenvolvido no âmbito do projecto e que culminará, assim se espera, na edição e tradução integral para língua portuguesa das quatro obras previstas de Dioscórides, Amato Lusitano e Pietro Andrea Mattioli. 
